\title{
Interannual Variation in Hydrologic Budgets in an Amazonian Watershed with a Coupled Subsurface-Land Surface Process Model ${ }^{\mathscr{O}}$
}

\author{
JIE NIU \\ Institute of Groundwater and Earth Science, Jinan University, Guangzhou, China, and Earth Sciences Division, Lawrence Berkeley National \\ Laboratory, Berkeley, and Earth Research Institute, University of California, Santa Barbara, Santa Barbara, California
}

\section{CHAOPENG SHEN}

Civil and Environmental Engineering, The Pennsylvania State University, State College, Pennsylvania

JEFFREY Q. CHAMBERS

Earth Sciences Division, Lawrence Berkeley National Laboratory, Berkeley, California

JOHN M. MELACK

Earth Research Institute, University of California, Santa Barbara, Santa Barbara, California

WILLIAM J. RILEY

Earth Sciences Division, Lawrence Berkeley National Laboratory, Berkeley, California

(Manuscript received 13 June 2017, in final form 17 July 2017)

\begin{abstract}
The central Amazon forest is projected to experience larger interannual precipitation variability, with uncertain impacts on terrestrial hydrologic fluxes. How surface runoff, groundwater, and evapotranspiration (ET) change as a function of annual precipitation (AP) has large climate and biogeochemical implications. A process-based hydrological model is used to examine the sensitivity of hydrologic budgets and stream discharge $Q_{s}$ generation to AP in an upland Amazon catchment. The authors find that AP strongly controls infiltration, base flow, and surface runoff, but not ET. Hence, AP alone can predict interannual changes in these fluxes except ET. Experiments with perturbed rainfall show the strong control derives from the predominant groundwater component that varies linearly with AP but is insensitive to seasonal rainfall fluctuations. Most rainfall from large storms infiltrates and becomes base flow rather than runoff or ET. Annual baseflow index (BFI; the fraction of stream discharge from base flow) is nearly constant $(\sim 0.8)$ when AP is below $\sim 2500 \mathrm{~mm} \mathrm{yr}^{-1}$ and decreases with AP above this value, which represents an inflection point for increased storage-dependent saturation excess. These results indicate that the system is energy limited and groundwater dominated in dry seasons, which implies some resilience of ET to moderate droughts. The results suggest AP is a good predictor for interannual changes in infiltration. Both the seasonal near-surface soil moisture and surface runoff are correlated more strongly to the subsurface fluxes than to precipitation over monthly and annual time scales. Finally, the results confirm the importance of central Amazon groundwater flow and its buffering effect on storms and droughts, implying needed model development in regional to global models.
\end{abstract}

Supplemental information related to this paper is available at the Journals Online website: https://doi.org/10.1175/JHM-D-170108.s1.

Corresponding author: J. Niu, jniu@jnu.edu.cn

\section{Introduction}

The Amazon forests manifest a water cycle in which the cycle was argued to effectively produce a monsoon for itself (Fu and $\mathrm{Li}$ 2004). Increased surface latent heat flux drives the dry-to-wet seasonal transition and results 
in increased rainfall (Fu and $\mathrm{Li}$ 2004). To sustain evapotranspiration (ET) during the dry season requires water stored from prior precipitation, indicating that subsurface processes, and especially groundwater, are critical for the water cycle of the tropical forests. As the Amazon is projected to experience larger interannual variability in precipitation (Stocker et al. 2013), how ET, groundwater flow, and surface water in the Amazon respond deserves improved understanding. Water flow and moisture within tropical forests affect many processes, including root-zone moisture availability for plants, transport of nutrients from land to rivers, nutrient release and transformation rates, and soil organic matter decomposition rates (Lesack and Melack 1996; Proctor 2004; Buss et al. 2010; Shanley et al. 2011; Eaton et al. 2012). As outgassing from rivers in the Amazon plays a significant role in the regional carbon cycle (Richey et al. 2002; Abril et al. 2006, Melack 2016), understanding the changes in streamflow components is important for understanding the transport of carbon to streams and rivers.

Most observationally based hydrologic studies in Amazonia have focused on large areas (da Rocha et al. 2004, 2009; Marengo 2004, 2005; Fisher et al. 2009), and the groundwater component is not observable in these studies (Marengo 2005; Tomasella et al. 2008). A few studies have examined small catchments with direct measurements. Franken and Leopoldo (1984) analyzed data from two small basins in central Amazonia and estimated the water budgets and the fraction of interception, runoff, transpiration, and ET relative to precipitation. Lesack (1993) found that storm flow contributed only about $3 \%$ to the discharge in a $0.23 \mathrm{~km}^{2}$ catchment in central Amazonia, while Leopoldo et al. (1995) found that base flow dominated the total discharge (91\%) in a $1.3 \mathrm{~km}^{2}$ catchment. Tomasella et al. (2008) reported that groundwater sustains streamflow and ET in years with rainfall deficiency. These observational studies indicate the importance of groundwater in the hydrologic system in tropical forests and that errors are likely if groundwater is not included in hydrologic models.

Most modeling studies at the Amazon basin scale have focused on land surface hydrologic fluxes, including ET, surface runoff, vegetation and soil water stores, soil drainage, and river-floodplain exchanges, but have not explicitly represented groundwater (Coe et al. 2008; Beighley et al. 2009; Paiva et al. 2013), which is a common issue among large-scale models (Clark et al. 2015). Several Amazon modeling studies have concluded that surface runoff is rare and groundwater plays a key role in the Amazon water cycle, accounting for more than $90 \%$ of river discharge as base flow (Leopoldo et al. 1995; Hodnett et al. 1997a,b; Cuartas 2008; Miguez-Macho and Fan 2012a). Across the whole
Amazon, Pokhrel et al. (2013) found that subsurface water accounts for more than $70 \%$ of water storage variation. However, these studies did not fully examine how interannual variability in energy and precipitation controls hydrologic responses. Therefore, it is important to better characterize how groundwater is related to discharge. This paper applies a process-based hydrologic model (PBHM) to an Amazonia basin to examine the influence of precipitation and subsurface flow on ET, stream discharge generation, and other components of hydrologic budgets.

PBHMs can be used to aid understanding of complex interrelated hydrologic processes (Ivanov et al. 2004; Maxwell and Miller 2005; Jia et al. 2006; Rigon et al. 2006; Shen and Phanikumar 2010; G.-Y. Niu et al. 2014; Tian et al. 2015). Getirana et al. (2014) concluded that a high level of complexity of physical processes represented by a model improved the representation of hydrological processes. We applied a PBHM because of its ability to simulate interacting states and fluxes that can be compared against observations and because of the fidelity to the underlying physics and biology at the watershed scale.

The Process-based Adaptive Watershed Simulator + Community Land Model (PAWS+CLM) solves physically based conservation laws for major processes in the hydrologic cycle as described in Shen and Phanikumar (2010) and J. Niu et al. (2014). PAWS uses a computationally efficient noniterative coupling method to link surface and subsurface processes (Shen and Phanikumar 2010), and its coupling to CLM4 (Oleson et al. 2010; Lawrence et al. 2011) provides process-based vegetation dynamics, surface energy cycles, and carbon cycling (Shen et al. 2013; Riley and Shen 2014). More details about the model are described in section 2c. PAWS + CLM has been tested against analytical solutions, laboratory data, field measurements, and satellite data, and has been applied to six watersheds located in the middle latitudes of North America (Ji et al. 2015; J. Niu et al. 2014; Niu and Phanikumar 2015; Pau et al. 2016; Riley and Shen 2014; Shen and Phanikumar 2010; Shen et al. 2013, 2014, 2016).

We applied and tested the PAWS+CLM in a $\sim 9000 \mathrm{~km}^{2}$ region (which we call the 4-River Region or 4RR watershed) near Manaus in central Amazonia. The region is representative of central Amazonian landscapes, has relevant hydrological data, and is sufficiently large to allow use of regional climatic data for forcing. We elucidate dynamics of the 4RR hydrologic system, including hydrologic fluxes, storage, and flow generation mechanisms for this upland tropical forested region. We analyze the relationship among different hydrologic components, for example, groundwater and surface 
runoff contributions to streamflow, ET, and precipitation, to address the following questions: What source of water could support significant ET near the end of the dry season? Is the supply available regardless of interannual differences in climate forcing? What controls the supply of water?

In section 2, we describe the site, data sources, and model. Section 3 describes (i) model comparisons with stream discharge, ET (using different precipitation datasets), and GRACE data; (ii) analyses of water budgets and contributions to streamflow generation; and (iii) analyses of correlation among different hydrologic fluxes. Finally, we discuss limitations of our approach and conclusions, indicate potential next steps, and summarize our results.

\section{Methods}

\section{a. Site description}

The watershed used in our analysis is located in the Amazonian tropical forest north of the city of Manaus, Brazil (Fig. 1). The $\sim 9000 \mathrm{~km}^{2}$ area of the $4 \mathrm{RR}$ watershed is composed of the upper reaches of four watersheds and is mostly covered with tropical forest with $\sim 12 \%$ cropland and $\sim 5 \%$ wetlands (based on CLM land surface data described below). The basins have an average slope of 3\% [digital elevation model (DEM) data described below] and include upper reaches of the Urubu, Preto da Eva, Tarumã-açu, and Tarumã-mirim Rivers. The upper landscape of the basins is composed mostly of plateaus (90-210 m), and the lower areas are broad swampy valleys $(45-55 \mathrm{~m})$ incised by a dense drainage network (Nobre et al. 2011).

We used $1 \mathrm{~km}^{2}$ horizontal spatial discretization, resulting in $118 \times 122$ grid cells for the $4 \mathrm{RR}$ watershed. Miguez-Macho and Fan (2012a,b) and Pokhrel et al. (2013) used $\sim 2-\mathrm{km}$ grids to simulate the entire Amazon and noted that their grid size did not adequately resolve the hill-valley gradients and the first-order streams. Our choice of the $1-\mathrm{km}^{2}$ grid resolution considers the model's computational efficiency such that parameter estimation is practical and keeps as much detail of land surface elevation as possible, although still not explicitly resolving the hill-valley gradients in this area. A 10-min time step was used for temporal discretization for overland and channel flows. For solving the Richards equation we used 20 vertical layers to discretize the vadose zone, considering the balance between computational demands and resolving near-surface soil water gradients. For the fully saturated groundwater domain, we used a thickness of
$100 \mathrm{~m}$ from the groundwater table to the bedrock. According to a geomorphological model-based estimate of soil and regolith thickness (Pelletier et al. 2016), the bedrock in the central Amazon is deep $(>50 \mathrm{~m})$ and exceeded the range of their model. We simulated two layers: the upper layer has clay and sand deposits, taken as the unconfined aquifer, and the lower layer is bedrock, taken as the confined aquifer. Adaptive time steps ranging from $10 \mathrm{~min}$ to $1 \mathrm{~h}$ were applied for the unsaturated zone and $1 \mathrm{~h}$ for the saturated groundwater and land surface processes.

\section{b. Data sources}

The DEM was obtained from the 90-m resolution NASA Shuttle Rader Topography Mission (SRTM) from the U.S. Geological Survey (USGS; http://eros. usgs.gov). The product grid of 3 arc $\mathrm{s}(\sim 90 \mathrm{~m})$ was aggregated to the $1000-\mathrm{m}$ model grid, using areal average interpolation, to calculate the slope and for surface runoff routing computations. The SRTM elevation was reported to locate $\sim 40 \%$ of the canopy height above ground in vegetated areas (Carabajal and Harding 2006). To adjust for the forest canopy, previous studies subtracted $20 \mathrm{~m}$ from the SRTM elevation (Miguez-Macho and Fan 2012a). Coe et al. (2008) subtracted $23 \mathrm{~m}$ for floodplain simulations, and Cuartas (2008) used linear regression to lower the elevation by $\sim 20 \mathrm{~m}$ on a watershed near Manaus. We subtracted the global 1-km forest canopy height data (see Fig. S1 in the online supplemental material; Simard et al. 2011) from SRTM elevations, which lowered the elevation by $\sim 28 \mathrm{~m}$ on average.

The channel network and the watershed boundary delineation are based on the $30-\mathrm{m}$ resolution Global Digital Elevation Model version 2 (GDEM V2) from the Advanced Spaceborne Thermal Emission and Reflection Radiometer (ASTER) and capture the correct shape of most streams including small tributaries. The highresolution GDEM data facilitates the delineation for small channels. The riverbed elevation was obtained from the corrected SRTM data by overlaying the delineated channel vectors, thus avoiding the inconsistency between the land surface and riverbed elevations.

We used several climate datasets to test the impact of climate forcing on model predictions. We compare their effects on different outputs of the model, first as an evaluation of the suitability of these forcing datasets for hydrologic modeling in the Amazon. More importantly, we find considerable differences in their characteristics (notably in frequency of large storms), so these comparisons provide tests of basin hydrologic responses and model sensitivity to precipitation distribution characteristics. Sources include the default 


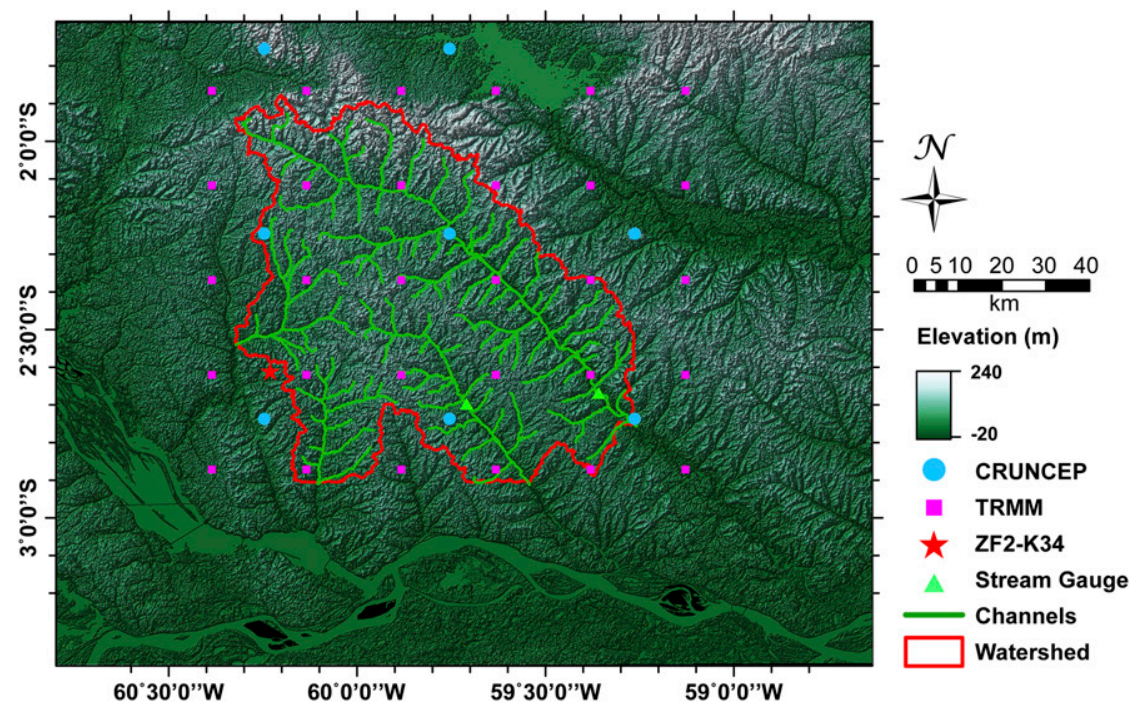

FIG. 1. Map of watershed used in study, showing DEM (NASA SRTM), channels (extracted from the ASTER GDEM V2), watershed boundary, stream gauges [ANA Hidroweb Sistema de Informações Hidrológicas gauge 15042000 in Preto da Eva River (left triangle) and gauge 16010000 in Urubu River (right triangle)], the centers of CRUNCEP (Piao et al. 2012) and TRMM (available at http://trmm.gsfc.nasa.gov/) data pixels, and the ZF2-K34 tower (ManausZF2 K34; $2.609^{\circ} \mathrm{S}, 60.209^{\circ} \mathrm{W}$; http://fluxnet.ornl.gov/site/76).

CLM CRU-NCEP (CRUNCEP) dataset (Piao et al. 2012) for climate forcing in 6-hourly and 0.5-arc-degree resolution (available from 1994 to 2013), including precipitation, temperature, humidity, short- and longwave solar radiation, wind speed, and land surface air pressure. We also performed simulations by replacing the precipitation data from the CRUNCEP data with the Tropical Measuring Mission (TRMM) 3B42 daily V7 precipitation data from NASA (available at http:// trmm.gsfc.nasa.gov/), which has $0.25^{\circ}$ spatial resolution (available from 1998 to 2013). We also replaced precipitation data with daily precipitation observations from a FLUXNET tower (Manaus-ZF2-K34; $2.609^{\circ}$ S, $60.209^{\circ} \mathrm{W}$; http://fluxnet.ornl.gov/site/76; Fig. 1) (available from 2001 to 2006 ). The $\sim 11 \%$ missing data from the tower observations were filled by the corresponding CRUNCEP precipitation. Data before 2001 and after 2006 are not available for the tower and were also filled by CRUNCEP precipitation. The tower is $\sim 1.5 \mathrm{~km}$ from the boundary of the 4RR watershed. Precipitation is prescribed to be spatially homogenous for the simulation domain when using the tower observations. In figures and tables in the later sections, without specific explanation, wherever we mention "simulation with TRMM (CRUNCEP or ZF2-K34)," it means the simulation was performed with TRMM (CRUNCEP or tower ZF2-K34) precipitation data, plus other climate forcing provided by CRUNCEP data.
We compared the seasonal variation of the TRMM, CRUNCEP, and ZF2-K34 tower measured precipitation, with error bars representing uncertainty. We used the TRMM and CRUNCEP pixels nearest to the tower for comparison (Fig. 2a). The three datasets have similar seasonal cycles, with distinct wet and dry seasons. However, particularly during the wetter months, mean TRMM precipitation is higher than CRUNCEP and ZF2-K34 estimates, while CRUNCEP and ZF2-K34 estimates are comparable throughout the year. During the period with available tower data, mean precipitation at the ZF2-K34 tower was $6.9 \mathrm{~mm} \mathrm{day}^{-1}$, while for the TRMM and CRUNCEP pixels corresponding to the tower location mean precipitation was 7.3 and $6.3 \mathrm{~mm} \mathrm{day}^{-1}$, respectively.

Mean precipitation integrated across the $4 \mathrm{RR}$ watershed was 6.7 and $6.1 \mathrm{~mm} \mathrm{day}^{-1}$ for the TRMM and CRUNCEP data, respectively, within the same time period. TRMM data have more frequent large storms (e.g., $>50 \mathrm{~mm} \mathrm{day}^{-1}$ ), while the CRUNCEP data have fewer large precipitation events than the tower data (e.g., $<30 \mathrm{~mm} \mathrm{day}^{-1}$; Fig. 2 b). The interannual variability of the monthly averaged TRMM data is larger than those of monthly CRUNCEP and tower precipitation, noting the large variation of TRMM data in the wet season in Fig. 2a. The variation of the daily coefficient of variation is from $\sim 0.01$ (wet season) to $\sim 2.8$ (dry season) based on CRUNCEP and from $\sim 0.2$ to $\sim 5.5$ based on TRMM. TRMM data have larger spatial and temporal variations 

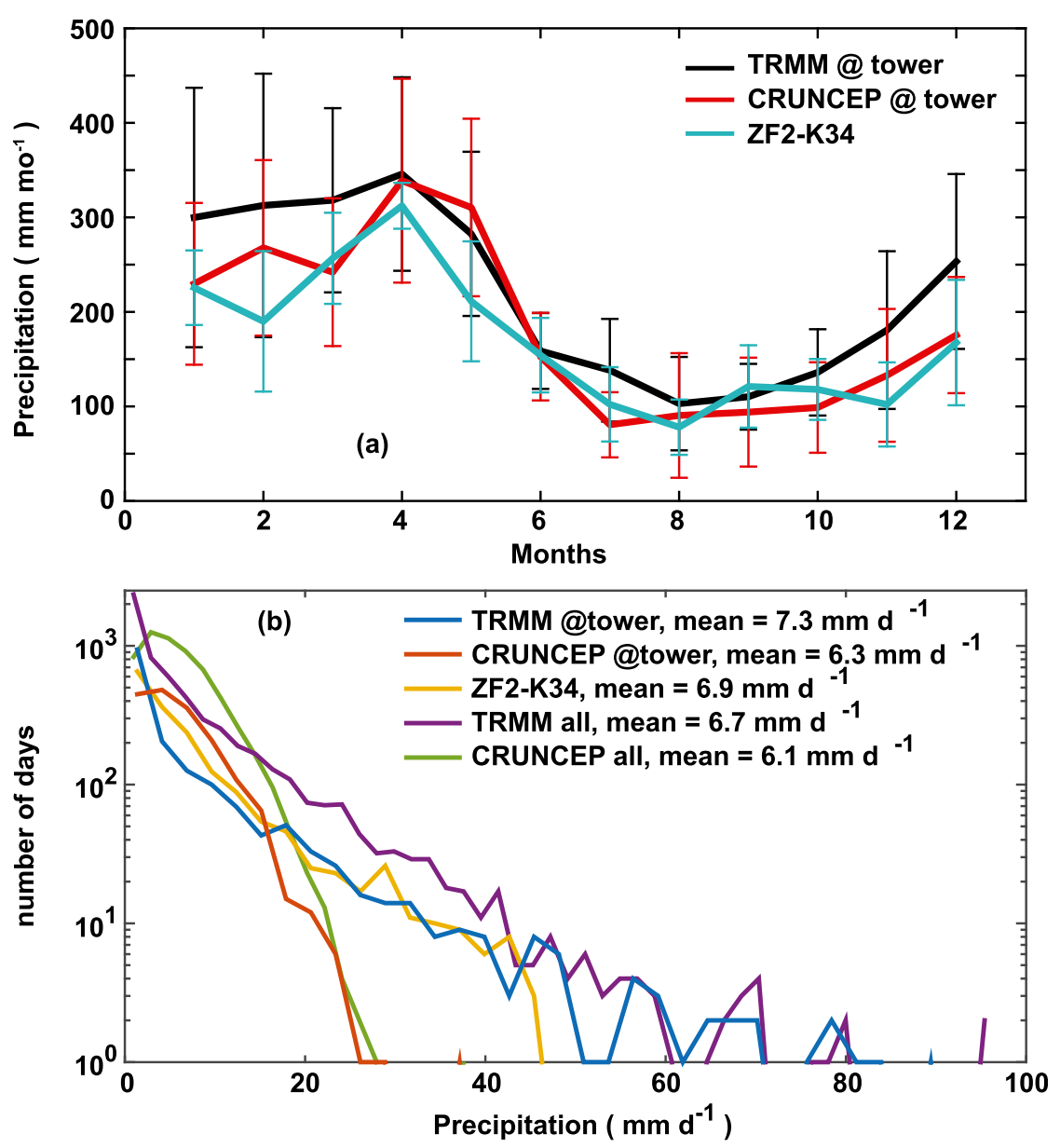

FIG. 2. Comparison of precipitation data among TRMM, CRUNCEP, and ZF2-K34 at, or close to, the tower. (a) Seasonal variation and (b) the number of days in each precipitation intensity bin. In (b) the $y$ axis represents the number of days (in $\log 10$ scale) and the $x$ axis shows the daily average precipitation amount. In the legends, "@ tower" means the data were extracted from TRMM or CRUNCEP grid pixels at or close to the ZF2-K34 tower, and "all" means it is the average across the entire watershed.

than CRUNCEP data. Monthly TRMM data have larger peaks every year compared to CRUNCEP data, especially in years with large mean annual precipitation (AP). For some years the lowest monthly CRUNCEP precipitation is smaller than TRMM data and was much smaller in 2010, a year with a major drought in the Amazonia basin. These differences explain our conclusion (discussed below) that the CRUNCEP precipitation inputs result in unrealistically low predicted peak stream discharges compared to observations.

Default CLM inputs that integrate satellite and historical 3-arc-min resolution land surface data (Oleson et al. 2013) were used for land use and land cover (LULC) data. Different sources of LULC maps normally have finer resolution than the model grid; thus in each model cell, there are often a number of different land uses, which need to be reclassified to the CLM plant functional types (PFTs; Shen et al. 2014). A maximum of nPFT land use types is allowed in a grid cell; $\mathrm{nPFT}$ is the preset number of simulated representative plants functional types in a cell. A simple one to one mapping is applied in this work to integrate the coarse default CLM PFT inputs to the model grid. For faster spinup of the hydrologic component, the 30-arc-s resolution groundwater table depth data (Fan et al. 2013) were used as initial groundwater head. We used the 5-arc-min resolution CLM soil texture and organic matter input data (Bonan et al. 2002) to calculate the Van Genuchten (VG) parameters for soil properties, using CalcPTF code (Guber et al. 2006, 2009). CalcPTF includes several different formulas and parameter sets to calculate VG parameters, for which the pedotransfer functions and 
parameters from Tomasella and Hodnett (1998) were chosen for tropical forests.

Stream discharge observations were obtained from the Agência Nacional de Águas (ANA) Hidroweb Sistema de Informações Hidrológicas (http://hidroweb. ana.gov.br/) at two stream gauges (15042000 in Preto da Eva River and 16010000 in Urubu River; Fig. 1) and were used for model calibration and testing. MODIS 16 monthly data (MODIS 16A2) were used for ET (http://www.ntsg.umt.edu/project/modis/mod16.php) comparison. The modeled ET data from Shuttleworth (1988) and the observations from flux tower ZF2-K34 were also used for comparison. The MOD16 global ET datasets have $1-\mathrm{km}$ resolution for vegetated land areas. The dataset covers the time period 2000-12. The previous ET product ( $\mathrm{Mu}$ et al. 2007) was compared to data from 19 eddy flux towers in North America. The latest ET product ( $\mathrm{Mu}$ et al. 2011) implements the improved ET algorithm in $\mathrm{Mu}$ et al. (2007) and agrees well with measurements from 46 eddy flux towers globally, including two towers in the Amazon basin. To analyze watershed storage changes, GRACE land grid equivalent water thickness data were downloaded from the University of Colorado Boulder (CU) interactive browser (http://geoid.colorado.edu/grace/dataportal. html). The CU GRACE data are processed similarly to the GRACE Tellus gridded land data (available at http://grace.jpl.nasa.gov/) and are appropriate for land hydrology applications (http://grace.jpl.nasa.gov/data/ get-data/interactive-browsers/). The CU GRACE data provide the most recent Release 5.0 (RL05) spherical harmonics from Jet Propulsion Laboratory (JPL), the Center for Space Research at the University of Texas (CSR), and GeoForschungsZentrum in Potsdam (GFZ). The distributed GRACE products have been "destriped" and smoothed using a 300-km-wide Gaussian filter to minimize north-south stripes. J. Niu et al. (2014) elaborated the details for calculating total water storage anomaly (TWSA) from multiple hydrologic components simulated in the model. Here we applied the same approach to calculate TWSA and compare against GRACE equivalent water thickness anomaly data in the studied area.

Detailed information for all datasets described in this section is listed in Table 1.

\section{c. Model description}

PAWS considers four flow domains-overland flow, channel flow, soil water flow, and saturated groundwater flow-and two subdomains-the ponding water layer and the flow domain - to separate water on the ground. Infiltration and evaporation occur in the ponding layer whereas water flows laterally on the surface from one cell to another in the flow domain. The mass balance equation for the ground surface ponding layer, which serves as the entry point and links the hydrologic processes, is presented in Eq. (1) in Shen and Phanikumar (2010). The two-dimensional diffusive wave equation is solved for modeling overland flow. The Richards equation is solved for infiltration in the soil column under normal conditions, whereas under heavy rainfall at dry surfaces the Green and Ampt equation (GA) is used to handle the situation and avoid the significant numerical error produced by Richards equation with affordable vertical gridcell discretization. The details about discretization and equation solvers have been described thoroughly in Shen and Phanikumar (2010) and Shen et al. (2014). When coupled to CLM, at each time step, CLM computes the surface energy balance, soil temperature, and canopy interception to provide PAWS boundary conditions, for example, ET demand (both transpiration and soil evaporation) as a function of depth. The soil hydrology module in CLM is replaced with its PAWS counterpart, which solves the Richards equation together with groundwater flow, runoff, overland flow, and streamflow. The resulting soil moisture states are then converted into the soil water state variables in CLM and fed back into CLM for calculations of ecosystem updates and soil and plant carbon and nitrogen cycles in the next time step, including photosynthesis, carbon allocation, and nitrogen constraints (Shen et al. 2013; Riley and Shen 2014).

\section{d. Model spinup and testing}

For model spinup, uncoupled CLM (i.e., not coupled with PAWS) was run from initial carbon and nitrogen states for 525 simulation years using the CRUNCEP climate forcing data and TRMM precipitation data from 1999 to 2013. We then used the uncoupled CLM spun-up state to initialize the carbon and temperature states in the PAWS+CLM simulation, which was performed for the same period (1999-2013) using the same climate forcing data. We evaluated the spun up state of the model by ensuring stable net ecosystem carbon balance (i.e., annual sum of net ecosystem exchange of carbon and the mean anomaly of total ecosystem carbon are small), and a reasonable LAI distribution (5.5-6.3; Fig. S2). The carbon and nitrogen states and soil temperature after spinup served as the initial conditions for the PAWS+CLM simulation.

We performed temporal linear correlation analyses on various predicted water budget components of the $4 R R$ watershed to 1) characterize the factors influencing the hydrologic water budgets and dynamics and 2) examine the interannual variability of the key hydrologic components using the monthly and annually averaged budgets. 
TABLE 1. Data sources and resolution.

\begin{tabular}{|c|c|c|c|}
\hline Data & Source & \multicolumn{2}{|c|}{ Resolution } \\
\hline \multirow[t]{2}{*}{ DEM } & ASTER GDEM V2 & $30 \mathrm{~m}$ & \\
\hline & NASA SRTM & $90 \mathrm{~m}$ & \\
\hline \multirow{3}{*}{ Weather } & CRUNCEP & 0.5 arc degree & 6 hourly \\
\hline & TRMM 3B42 V7 precipitation data & 0.25 arc degree & Daily \\
\hline & FLUXNET tower (Manaus-ZF2 K34) precipitation measurement & Point & Daily \\
\hline LULC & CLM input incorporated with satellite and historical land surface data & $3 \operatorname{arc} \min$ & \\
\hline Soil & CLM soil texture and organic matter input & $5 \operatorname{arc} \min$ & \\
\hline Groundwater & Fan et al. (2013), science, global patterns of groundwater table depth & $30 \operatorname{arcs}$ & \\
\hline Discharge & $\begin{array}{l}\text { ANA Hidroweb Sistema de Informações Hidrológicas (15042000 in } \\
\text { Preto da Eva River and } 16010000 \text { in Urubu River) }\end{array}$ & & Daily \\
\hline ET & MODIS, MOD16A2 & $1 \mathrm{~km}$ & Monthly \\
\hline Storage & GRACE, land grid equivalent water thickness & 1 arc degree & Monthly \\
\hline
\end{tabular}

Model stream discharge calibration parameters are described in Table S1, including hydraulic conductivities, the van Genuchten soil parameters, and riverbed leakance. The spatially varied parameters are adjusted by multiplying or adding a constant. Thus, they can be uniformly increased or decreased, in order to retain the natural variability and the spatial heterogeneity in the original data. Based on the differential evolution algorithm (Price et al. 2005), parameter estimation was performed to minimize the objective function combined with the Nash-Sutcliffe efficiency metric (NASH) and the square root-transformed NASH metric (RNASH). These two metrics calculate the differences between simulated and observed stream discharge at two stream gauges (15042000 in Preto da Eva River and 16010000 in Urubu River; Fig. 1). More details about the model calibration technique were described in J. Niu et al. (2014).

\section{e. Experiments with perturbed precipitation}

For the period of simulation, there is no value of AP between 2600 and $2800 \mathrm{~mm} \mathrm{yr}^{-1}$. To better examine streamflow sources as functions of precipitation within this range, we increased the precipitation by factors of $1.05,1.10,1.15$, and 1.20 of the original amount from TRMM. In addition, we ran simulations with precipitation increased to 1.20 times its original amount from May to November only each year, and for the same amount of rainfall added from December to April only. These experiments examine the impacts of seasonal precipitation variations on base flow and overland flow. The amounts of AP for the synthetic simulations range from $\sim 2000$ to $\sim 3600 \mathrm{~mm} \mathrm{yr}^{-1}$.

\section{Results and discussion}

We separate our results and discussion into six subsections. The first subsection presents extensive comparisons with observations for stream discharge, ET, and groundwater storage. These comparisons provide a basic description of the hydrologic context of the basin and an assessment of the model. The components and temporal variability of ET are discussed in the second subsection. The third and fourth subsections examine surface runoff and groundwater contributions to streamflow and their interannual variability as functions of AP. In the fifth subsection, we discuss predicted temporal correlations between climate forcing and hydrologic variables and explain relationships among different hydrologic states and fluxes. Finally, in the sixth subsection, we discuss limitations associated with the model predictions, uncertainties, and future research directions. We compare outputs from three forcing datasets throughout the analyses. As discussed earlier, the comparison among precipitation datasets presents not only an assessment of inputs but also a sensitivity test of the system to different precipitation distribution patterns.

\section{a. Comparison with observations}

\section{1) StreAmFlow}

The choice of precipitation dataset affects the stream discharge significantly, which helps us evaluate the quality of precipitation forcing (Fig. 3). CRUNCEP precipitation data likely have a large bias toward low values because they fail to reproduce most of the observed peak discharge at both gauges. The poor performance of CRUNCEP precipitation was also observed when the model parameters were calibrated with the CRUNCEP precipitation dataset (data not shown). In contrast, with TRMM precipitation inputs the simulation generally matches the observations for both gauges (NASH $=0.4$ for gauge 15042000 and $\mathrm{NASH}=0.8$ for gauge 16010000). Tower precipitation measurements are slightly larger than those of CRUNCEP averaged over 

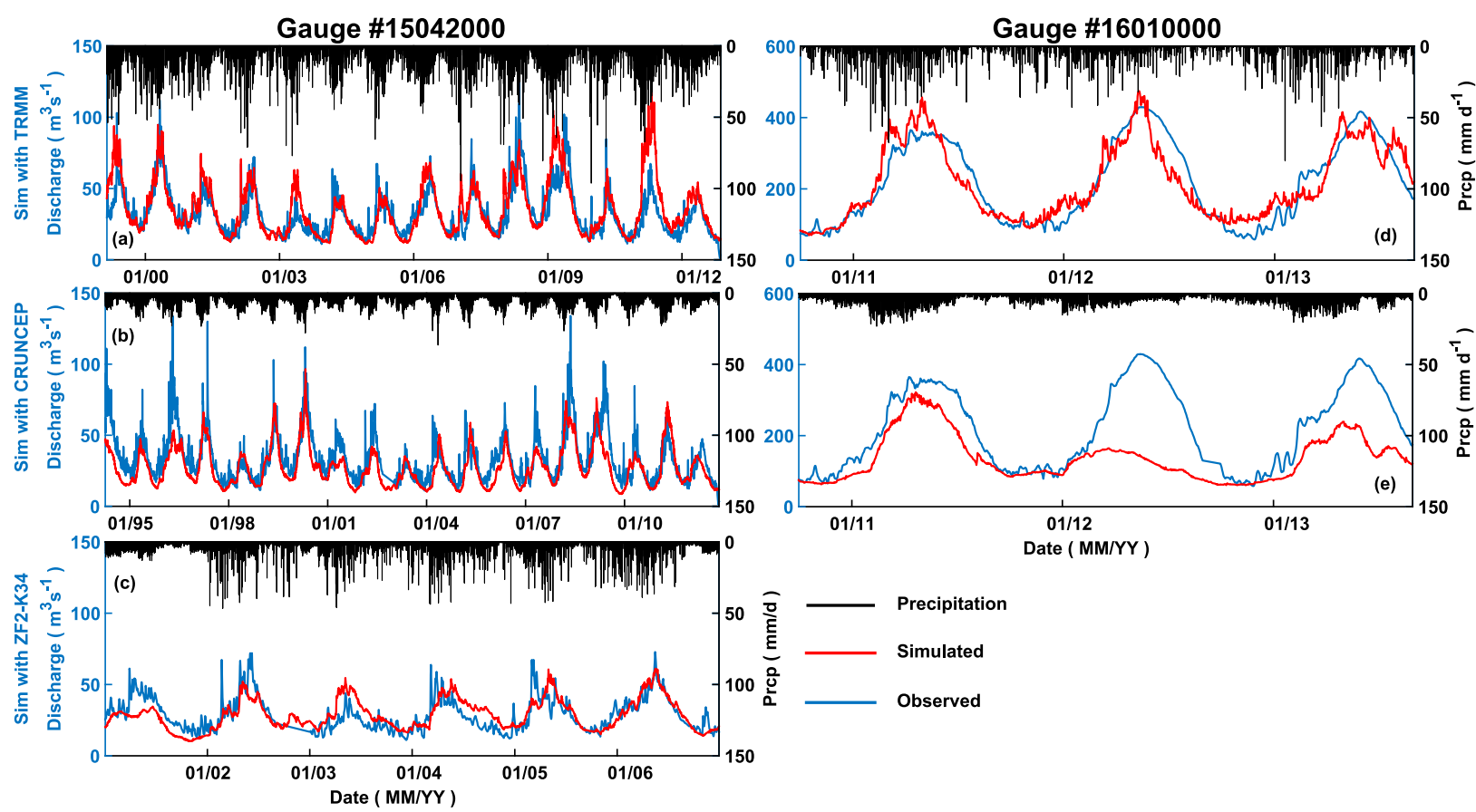

FIG. 3. Daily stream discharge comparisons at two gauges for three precipitation inputs (CRUNCEP, TRIMM, ZF2-K34 tower) superimposed on the CRUNCEP climate forcing. The daily-averaged results are presented for the period in which both gauge measurements and precipitation data were available. The ZF2-K34 tower precipitation measurements started in August 2001 and ended in August 2006 and did not overlap the discharge observations from gauge 16010000 (note the different time ranges for each subplot). (left) Gauge 15042000, and (right) gauge 16010000. Black lines show the daily precipitation from (a),(d) TRMM data; (b),(e) CRUNCEP precipitation data; and (c) tower ZF2-K34 precipitation data on the top axes. Blue lines are the gauge observations, while red lines are the simulations with different precipitation data.

the $4 \mathrm{RR}$ basin. During the period of available tower measurements, the simulated peak discharge with tower precipitation data outperforms that with CRUNCEP data. However, when we applied the tower precipitation data to the entire 4RR watershed, which makes the precipitation forcing spatially homogeneous, the tower-dataforced simulation performed less well because of the spatial heterogeneity of natural rainfall. The simulation with CRUNCEP precipitation failed to capture peak discharges, especially in wet years with large discharge. For gauge 16010000, CRUNCEP precipitation input is insufficient to match the hydrograph for two consecutive years, 2012 and 2013. We investigated further the different precipitation data and how they affect the seasonality of the fractional composition of stream discharge in relation to the runoff-generating mechanism in the following sections.

\section{2) EVAPOTRANSPIRATION}

Compared to the MODIS ET product, PAWS + CLM simulated average monthly ET has about the same seasonal amplitude $\left(\sim 1 \mathrm{~mm} \mathrm{day}^{-1}\right)$. The ET predictions with TRMM precipitation match the MODIS ET well over the year. Compared to MODIS ET, predictions with CRUNCEP and tower precipitation inputs are slightly lower in August and September (dry season) and slightly higher in March-May (wet season; Fig. 4). Simulated ET with CRUNCEP and ZF2-K34 tower precipitation data are slightly larger than with TRMM throughout the year, except for the dry season. All three simulations have higher ET in the dry season, as does the MODIS product.

The differences between model predictions and the MODIS ET product can be attributed to the modeling approaches: PAWS+CLM uses a resistance approach based on the two-big-leaf model (Dai et al. 2004) and couples leaf photosynthesis with stomatal conductance, thereby affecting ET, while the MODIS product is based on satellite observations of the normalized difference vegetation index (NDVI) to estimate the surface resistance and then the Penman-Monteith formulation to estimate ET (Mu et al. 2007, 2011). The remote sensing signal received by the MODIS satellite sensor is affected by clouds and aerosols, and by changes in the angle between the sensor and the sunlight direction and associated shadowing (Chambers and Roberts 2014; 


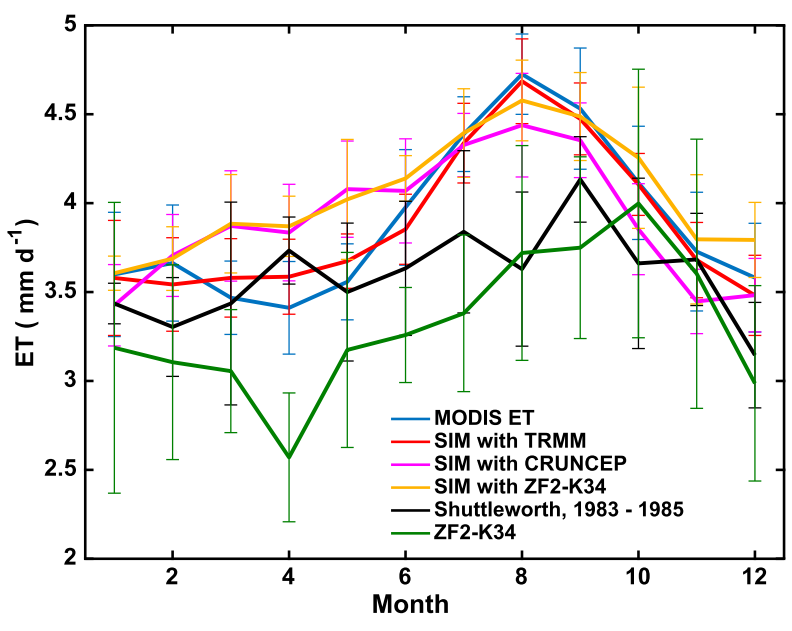

FIG. 4. Seasonal ET comparisons between MODIS 16A2 monthly ET product, ET simulations with TRMM, CRUNCEP, and ZF2-K34 precipitation inputs; ET calculation from Shuttleworth (1988); and derived ET data from tower ZF2-K34. Curves are the mean values, and the error bars are the standard deviation.

Morton et al. 2014). Moreover, the sensors only measure the change in the upper forest canopy (Chambers and Roberts 2014), while the model simulates whole ecosystem responses. Modeled ET data from September 1983 to September 1985 in Shuttleworth (1988) and ET converted from latent heat measurement at ZF2-K34 are also shown in Fig. 4. Shuttleworth's ET simulation has smaller amplitudes of seasonal variation, while ZF2-K34 dataset has about the same seasonal amplitudes (but smaller amount), compared to our simulated ET and the MODIS product. Shuttleworth's predictions have an annual peak in September, but tower data have a peak in October. The tower ET data may be lower due to a small surrounding area, while the others are areal averages. The mean annual ET estimated by Tomasella et al. (2008) in the Asu catchment $\left(6.6 \mathrm{~km}^{2}\right)$, adjacent to our study area, was $\sim 1400 \mathrm{~mm} \mathrm{yr}^{-1}$, which is comparable to our simulation with TRMM $\left(1562 \mathrm{~mm} \mathrm{yr}^{-1}\right)$ and MODIS ET (1422 $\left.\mathrm{mm} \mathrm{yr}^{-1}\right)$.

\section{3) Storage}

The Amazon forest has a large annual TWSA fluctuation as a fraction of annual precipitation (Fang et al. 2016), showing the system's ability to retain water. The simulated TWSA generally agrees well with GRACE data except for a few mismatches of either peak or trough values in some years, for example, over- and underestimation of peak anomalies in 2010 and 2011, respectively, and overestimation of the trough in 2008 (Fig. 5). The simulation with CRUNCEP precipitation inputs often has slightly lower values for the peak TWSA than the simulation with TRMM data. The simulation with tower precipitation input is comparable to that with CRUNCEP data from May 2001 to December 2006, except that using the tower data results in larger TWSA values for the troughs. Over the entire simulation period, TWSA seasonal variation simulated with tower precipitation deviates from those with CRUNCEP and TRMM input, with the former possibly due to the lack of spatial heterogeneity when applying the tower data to the whole 4RR watershed. However, differences between TWSA seasonal variations simulated with CRUNCEP precipitation and with TRMM data are small, unlike our predictions for stream discharge, in which different precipitation data resulted in substantial differences (section 3a). In temperate watersheds, water storage changes in subsurface compartments dominate the TWSA signal (J. Niu et al. 2014). For Amazonian basins, groundwater components can be significant even if the water table is deep (Pokhrel et al. 2013). Thus, the comparisons between simulated TWSA and between stream discharges using different precipitation forcing show that the groundwater system in the 4RR watershed has a large buffering capacity, and changes in groundwater depth are therefore relatively insensitive to precipitation, unlike the other predicted hydrologic fluxes, for example, stream discharge.

Mismatches between the simulated and GRACE TWSA can be attributed to differences in spatial resolution of GRACE data and the region in this study. For example, a smoothing radius of $300 \mathrm{~km}$ was used to reduce high-frequency noise in high-order spherical harmonics associated with the GRACE data, while the spatial extent of the $4 \mathrm{RR}$ watershed is $\sim 100 \mathrm{~km}$. In valleys and floodplains and where the water table is shallow, subsurface water storage is nearly saturated, and surface runoff and flooding dominate the TWSA signal (Pokhrel et al. 2013). As the 4RR watershed is close to two major rivers (Negro and Amazon), and because of the large footprint and 300-km Gaussian filter used in the GRACE product, we expect a noticeable error from the seasonally fluctuating Amazon and Negro Rivers to influence the TWSA in the 4RR watershed.

\section{b. ET components and interannual variability}

Predicted annual canopy evaporation is $\sim 20 \%$ of annual precipitation and $\sim 30 \%$ of annual ET $(31 \%$ with CRUNCEP precipitation, 29\% with ZF2-K34 precipitation, and $28 \%$ with TRMM precipitation; Table 2). Previously reported canopy evaporation values range from $4 \%$ to $37 \%$ of total AP for tropical forests (Dingman 2002; Wang et al. 2007), from 12\% to $25 \%$ across wet and dry seasons and normal and drier years in the central Amazon near Manaus (Cuartas 2008; Miguez-Macho and Fan 2012b), and 


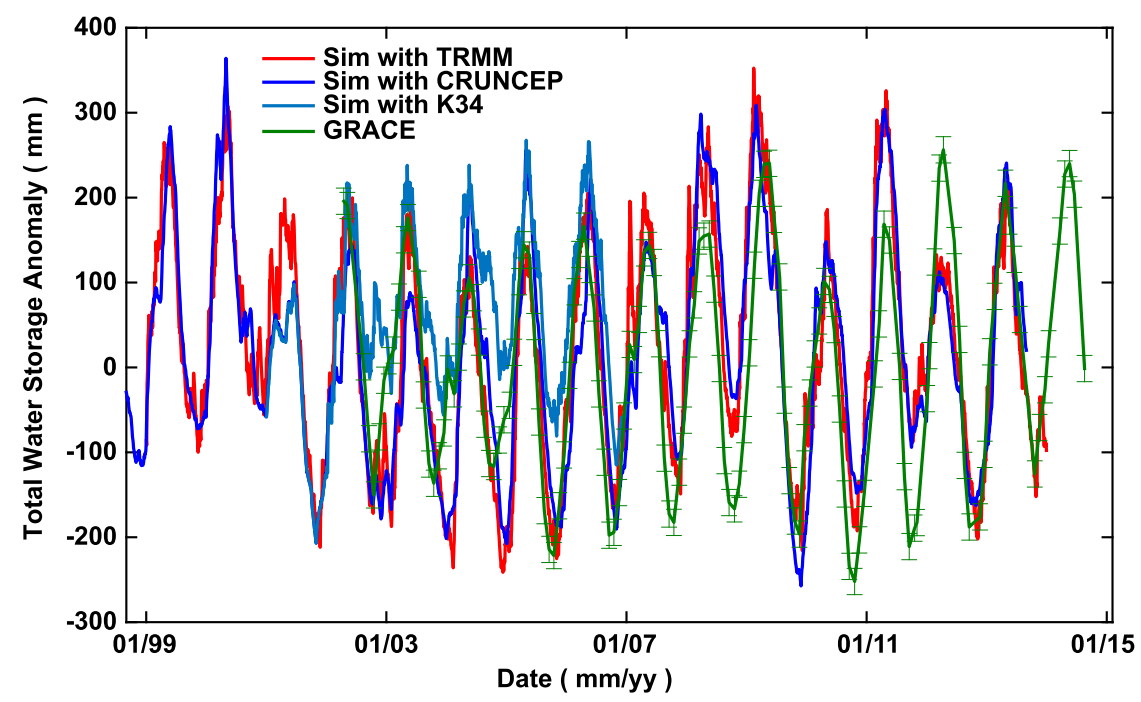

FIG. 5. Comparison of TWSA between GRACE data and model simulations. The green line is the GRACE data with error bars (calculated from leakage and measurement errors provided using the algorithm in GRACE production description online), the red line is the simulation with TRMM precipitation input, the dark blue line is the simulation with CRUNCEP precipitation input, and the light blue line is the simulation with ZF2-K34 precipitation input. The starting and ending times in the figure correspond to the available time period for TRMM precipitation (starting from September 1998) and GRACE data (ending in December 2014). Tower measurements are only available from August 2001 to August 2006.

from $8 \%$ to $12 \%$ across light to heavy rain-rate daytime events in the eastern Amazon near Santarem (Czikowsky and Fitzjarrald 2009). Miguez-Macho and Fan (2012b) concluded that interception and canopy evaporation are commonly overestimated in global land models because of lower predicted storm intensity introduced by averaging over large grid cells and/or time steps, and parameterizations of interception. In our simulations, the ratio of canopy evaporation to ET is slightly higher $(\sim 36 \%)$ in the wet season (from November to May) than annual averages. Our predicted ratios of annual canopy evaporation to ET are within the range observed in the central Amazon near Manaus, that is, $12 \%-25 \%$ (Cuartas 2008 ) and $20 \%-25 \%$ (Shuttleworth 1988).

The three different precipitation inputs led to comparable predicted ET, transpiration, ground evaporation, and evaporation from canopy interception (referred to here as canopy evaporation). Annual ET simulated with the three precipitation inputs are comparable: 1618,1562 , and $1659 \mathrm{~mm} \mathrm{yr}^{-1}$ for simulations with CRUNCEP, TRMM, and ZF2-K34 measurements, respectively (Table 2). The TRMM mean AP (averaged from January 1999 to December 2013) for the entire 4RR watershed is $\sim 2500 \mathrm{~mm}$, which is $\sim 300$ and $\sim 100 \mathrm{~mm}$ more than those of CRUNCEP (averaged from January 1994 to August 2013) and the tower
ZF2-K34 observations (averaged from August 2001 to August 2006), respectively (Table 2). The three precipitation datasets for the simulated watershed each indicate more than $2000 \mathrm{~mm} \mathrm{yr}^{-1}$, which leads to an evergreen state throughout the dry season (Guan et al. 2015). Pokhrel et al. (2013) found that the water table is shallow in northwestern and floodplains of Amazonia and that water stores in the subsurface, including vadose zone and groundwater, are nearly saturated year round. Differences in precipitation amounts in the three forcing datasets did not produce similar differences in simulated ET.

Several previous studies revealed different mechanisms for how subsurface storage sustains ET, such as upward capillary flux and deep root uptake (Christoffersen et al. 2014; Markewitz et al. 2010), and hydraulic redistribution that can increase dry season transpiration (Lee et al. 2005; Tang et al. 2015). PAWS implements a sophisticated groundwater module, and our simulations support the hypothesis that groundwater sustains ET during the dry season for this part of the Amazon.

\section{c. Surface runoff and groundwater contributions to streamflow}

With the larger precipitation inputs in the TRMM data, the simulated annual infiltration, groundwater 
TABLE 2. Annual averaged water budgets simulated with different precipitation data (1994-2013 for CRUNCEP, 1998-2013 for TRMM, and 2001-06 for ZF2-K34), and their portions according to annual precipitation (\% Precipitation) and ET (\% ET). Parameter $Q_{G}$ is groundwater contribution to streamflow.

\begin{tabular}{|c|c|c|c|c|c|c|c|c|c|}
\hline & $\begin{array}{l}\text { CRUNCEP } \\
\left(\mathrm{mm} \mathrm{yr}^{-1}\right)\end{array}$ & $\%$ Precipitation & $\%$ ET & $\begin{array}{c}\text { TRMM } \\
\left(\mathrm{mm} \mathrm{yr}^{-1}\right)\end{array}$ & $\%$ Precipitation & $\% \mathrm{ET}$ & $\begin{array}{c}\mathrm{K} 34 \\
\left(\mathrm{~mm} \mathrm{yr}^{-1}\right)\end{array}$ & $\%$ Precipitation & $\%$ ET \\
\hline Precipitation & 2205 & 100 & - & 2479 & 100 & - & 2299 & 100 & - \\
\hline $\mathrm{ET}$ & 1618 & 73 & 100 & 1562 & 63 & 100 & 1659 & 72 & 100 \\
\hline Transpiration & 951 & 43 & 59 & 974 & 39 & 62 & 1008 & 44 & 61 \\
\hline $\begin{array}{l}\text { Ground } \\
\text { evaporation }\end{array}$ & 172 & 8 & 11 & 152 & 6 & 10 & 179 & 8 & 11 \\
\hline $\begin{array}{l}\text { Canopy } \\
\text { evaporation }\end{array}$ & 494 & 22 & 31 & 436 & 18 & 28 & 472 & 21 & 29 \\
\hline Infiltration & 1232 & 56 & - & 1747 & 71 & - & 1316 & 57 & - \\
\hline Surface runoff & 322 & 15 & - & 204 & 8 & - & 359 & 16 & - \\
\hline$Q_{G}$ & 287 & 13 & - & 744 & 30 & - & 354 & 15 & - \\
\hline Recharge & 287 & 13 & - & 744 & 30 & - & 353 & 15 & - \\
\hline Stream outflow & 609 & 28 & - & 947 & 38 & - & 713 & 31 & - \\
\hline
\end{tabular}

contributions to stream discharge, deep percolation, and stream outflow are all larger than those simulated with precipitation from CRUNCEP or the tower measurements. Both CRUNCEP and tower precipitation inputs have different storm timing, fewer storm events, and low mean AP compared to TRMM, as discussed in section 2 b. Infiltration values simulated with TRMM data are significantly larger than those using CRUNCEP and ZF2-K34 precipitation data (Table 2). The comparison shows that the extra precipitation from TRMM is not predicted to be intercepted by, and reevaporated from, the canopy. Since surface runoff does not account for a large portion of precipitation and there are no significant differences in ET, most precipitation during even large storms infiltrates rather than evaporating or becoming direct runoff. This comparison highlights that the substantial storage capability of the Amazon soils has a large influence on hydrologic responses.

During the wet season, stream discharge is mainly generated by groundwater (as inferred from the simulation with TRMM). The amount of simulated surface runoff is not strongly affected by differences in precipitation forcing. However, the simulated infiltration, groundwater recharge, and groundwater contribution to stream discharge increased noticeably with increasing AP. The ratio of annual mean groundwater contribution $Q_{G}$ to stream discharge $Q_{S}\left[Q_{G} / Q_{S}\right.$; also the fraction of stream discharge from base flow, or baseflow index (BFI)], is about 0.8 for the simulation with TRMM precipitation data (Fig. 6d), which is comparable to that in previous modeling analyses (BFI are $>0.5$ or even 1 ; see the Asu subplot in Fig. 11 in Miguez-Macho and Fan 2012a) for drainage basins close to the one in this work. Miguez-Macho and Fan (2012a) mentioned that their $\sim 2-\mathrm{km}$ grid size was not able to fully differentiate the hill-valley gradients and the first-order streams, while here we use a $1-\mathrm{km}$ grid and arrive at generally comparable values of BFI.

Mean values and seasonal variations of BFI change when forced with different precipitation data. For example, the mean BFI is $\sim 0.4$ using CRUNCEP and tower precipitation data, and the seasonal amplitudes are $\sim 0.1$ using TRMM but $\sim 0.3$ using CRUNCEP precipitation data (Figs. 6d-f). As discussed above, PAWS + CLM underpredicted stream discharge when CRUNCEP and ZF2-K34 tower precipitation inputs were used. The heavier storms from TRMM compared to two other forcings do not cause larger surface runoff but instead lead to larger flow through the groundwater component. This pattern again highlights the dominating influence of groundwater flow in the simulated hydrologic cycle: even larger storms can infiltrate and exit as groundwater flow in the Amazon basin. Predicted stream discharge and baseflow contributions to streams are larger with the higher TRMM precipitation than with the two other precipitation datasets (both in absolute and in proportion to precipitation).

The seasonal variability of the hydrograph and BFI are the same using TRMM forcing (Figs. 6a-c), both corresponding to the seasonality of precipitation, but are generally opposite to that of water table depth (Figs. 6d-f). It is reasonable that water table depth has a different seasonal cycle since the groundwater storage filled by precipitation in the wet season slowly releases and supports a large portion of the stream outflow in the dry season. Groundwater supports the bulk of total streamflow, especially in the dry season, for all three precipitation-forcing scenarios, consistent with previous 

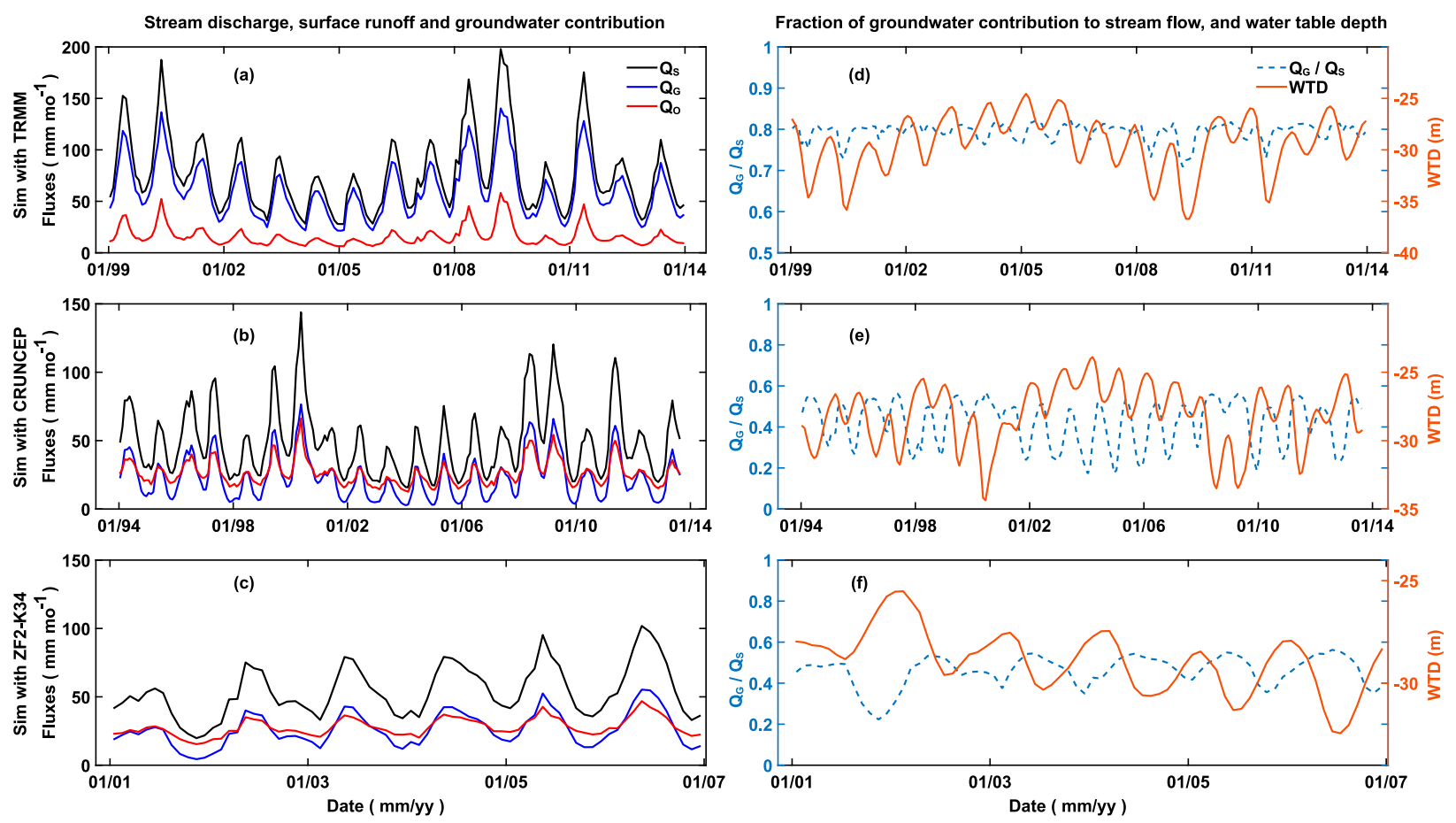

FIG. 6. Time series of $Q_{S}$ (summed up for all outlets), $Q_{O}$, and $Q_{G}$ for the entire watershed with (a) TRMM, (b) CRUNCEP, and (c) ZF2-K34 precipitation inputs. (d)-(f) As in (a)-(c) but for the fraction of groundwater contributed to streamflow $\left(Q_{G} / Q_{s}\right.$; dashed lines) and the time series plots of mean groundwater table depth (WTD; solid lines) of the entire watershed. Each row has different starting and ending times due to differences in precipitation input data availability.

studies in the nearby basins mentioned above. In many parts of the world, groundwater supports base flow, while the peak flow is generated by storm events. However, this is not the case in our study, and, regardless of precipitation forcing data used, groundwater dominated stream discharge generation for both low and peak flow. Water table depth peaked prior to the peak flow and the peak of BFI each year as simulated infiltration, and deep percolation increased substantially with increasing AP. For those years with extreme events, for example, in years 2000, 2008, 2009, and 2011 with large storms, water table and BFI changed considerably (Figs. 6d,e); in contrast, in years 2004, 2005, and 2010 with smaller mean AP, the water table rose and $\mathrm{BFI}$ varied less significantly.

\section{d. Stream discharge contributions as a function of $A P$}

The interannual contribution of annual mean overland flow $Q_{O}$ to stream discharge $Q_{O} / Q_{S}$ increases, while BFI decreases nonlinearly, with increasing AP above about $2500 \mathrm{~mm} \mathrm{yr}^{-1}$ (Fig. 7a); below that value, the variations are relatively small (approximately constant at $\sim 0.8$ for BFI and $\sim 0.2$ for $\left.Q_{O} / Q_{S}\right)$. There was no value of AP between 2600 and $2800 \mathrm{~mm} \mathrm{yr}^{-1}$ during the years of simulation; thus, we designed modeling experiments with increased rainfall as described in section $2 \mathrm{~d}$. These experiments allow almost continuous AP ranging from $\sim 2000$ to $\sim 3600 \mathrm{~mm} \mathrm{yr}^{-1}$. Two separate curves can be fitted to $Q_{G} / Q_{S}$ and $Q_{O} / Q_{S}$ on Fig. 7, with the inflection points around $\sim 2500 \mathrm{~mm} \mathrm{yr}^{-1}$, below which the slopes of the two curves are small, but above which the slopes decrease $\left(Q_{G} / Q_{S}\right)$ or increase $\left(Q_{O} / Q_{S}\right)$. When we increase the amounts of precipitation for dry seasons only, for the same amount of AP smaller or around $\sim 2500 \mathrm{~mm} \mathrm{yr}^{-1}$, BFI tends to be higher but $Q_{O} / Q_{S}$ remains low compared to other cases (Fig. 7a). When we increase the amounts of precipitation for rainy seasons only, BFI decreases and $Q_{O} / Q_{S}$ increases more rapidly for larger AP $\left(>\sim 2500 \mathrm{~mm} \mathrm{yr}^{-1}\right)$. We can see that $Q_{O}$ increases nonlinearly while $Q_{G}$ increases linearly (Fig. 7b), which is especially clear when AP $>2700 \mathrm{~mm} \mathrm{yr}^{-1}$, indicating an inflection point for saturation excess. These relationships between $\mathrm{BFI}, Q_{O} / Q_{S}$, and $\mathrm{AP}$ indicate that groundwater buffers large amounts of precipitation input year round, but more storage-dependent surface runoff, that is, saturation excess, starts to occur above an AP of $\sim 2500 \mathrm{~mm} \mathrm{yr}^{-1}$. As a result, the ratio of overland flow contributions increases due to increased saturation excess. Although the change is large when AP is greater than $\sim 2500 \mathrm{~mm} \mathrm{yr}^{-1}$ (Fig. 7a), the maximum relative change for BFI is only $\sim 7 \%$, but larger for $Q_{O} / Q_{S}(\sim 24 \%)$, for 


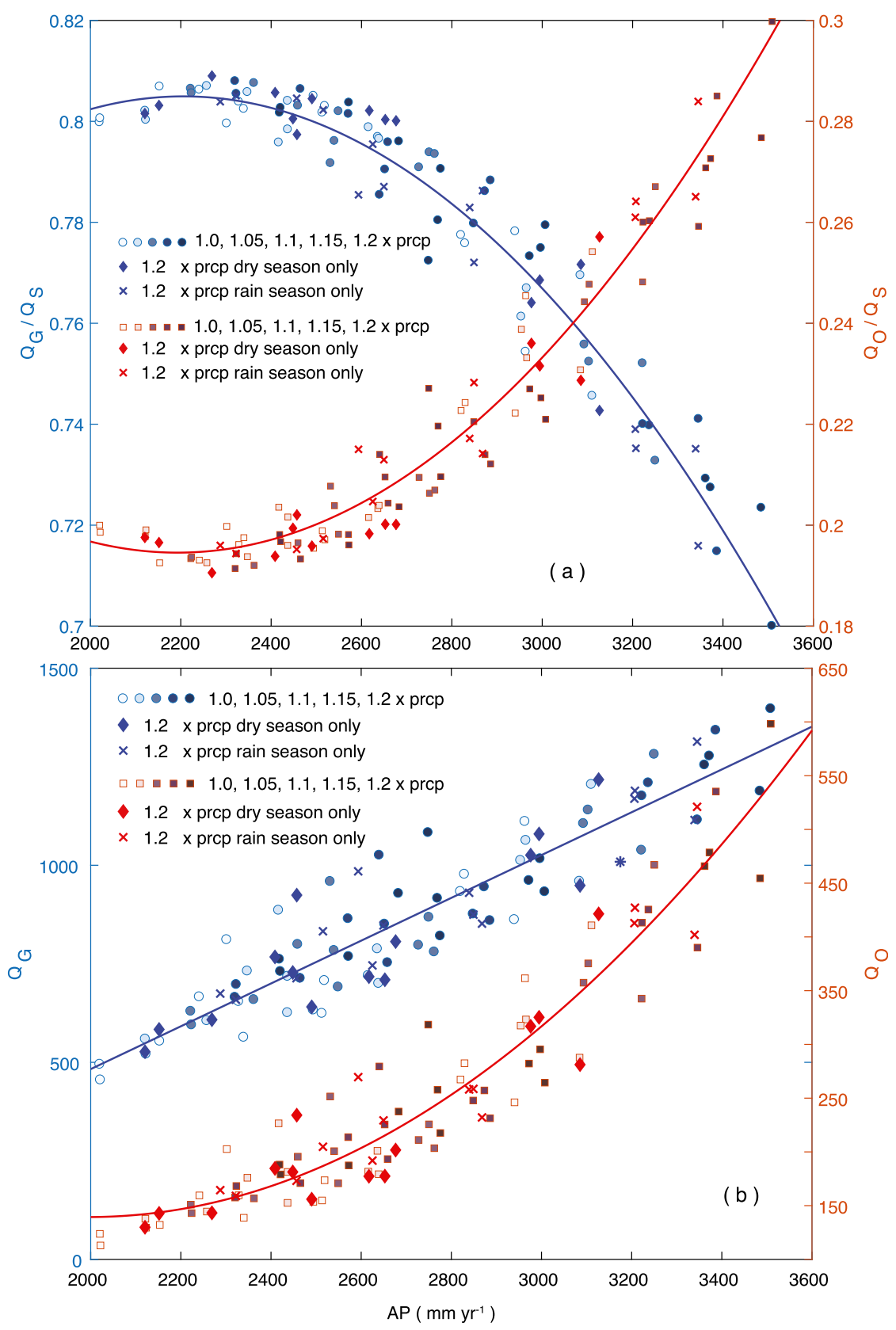

FIG. 7. (a) Mean annual $Q_{S} / \mathrm{AP}, Q_{O} / \mathrm{AP}$, and $Q_{G} / \mathrm{AP}$ for the entire watershed with original and increased (by factors of 1.05, 1.1,1.15, and 1.2) TRMM precipitation inputs, and with increased $(1.2 \times)$ TRMM inputs for dry and rainy seasons only. The blue dots, diamonds, and crosses represent $Q_{G} / Q_{S}$, and the red squares, diamonds, and crosses are $Q_{O} / Q_{S}$. (b) $Q_{O}$ and $Q_{G}$ to AP for the entire watershed with original and increased (by factors of 1.05, 1.1, 1.15, and 1.2) TRMM precipitation inputs, and with increased (1.2×) TRMM inputs for dry and rainy seasons only. The blue dots, diamonds, and crosses represent the $Q_{G}$, and the red squares, diamonds, and crosses are $Q_{O}$. The blue and red lines are the fitting curves. The abbreviation "prcp" stands for precipitation.

simulation with the original precipitation data only. We also note that base flow is strongly controlled by AP and the same linear trend holds regardless of the extent of perturbation.
When we added the same amount of rainfall to the dry and wet seasons, respectively, the changes in baseflow contribution are controlled only by AP, not the season to which it was added, as shown by the high correlation 

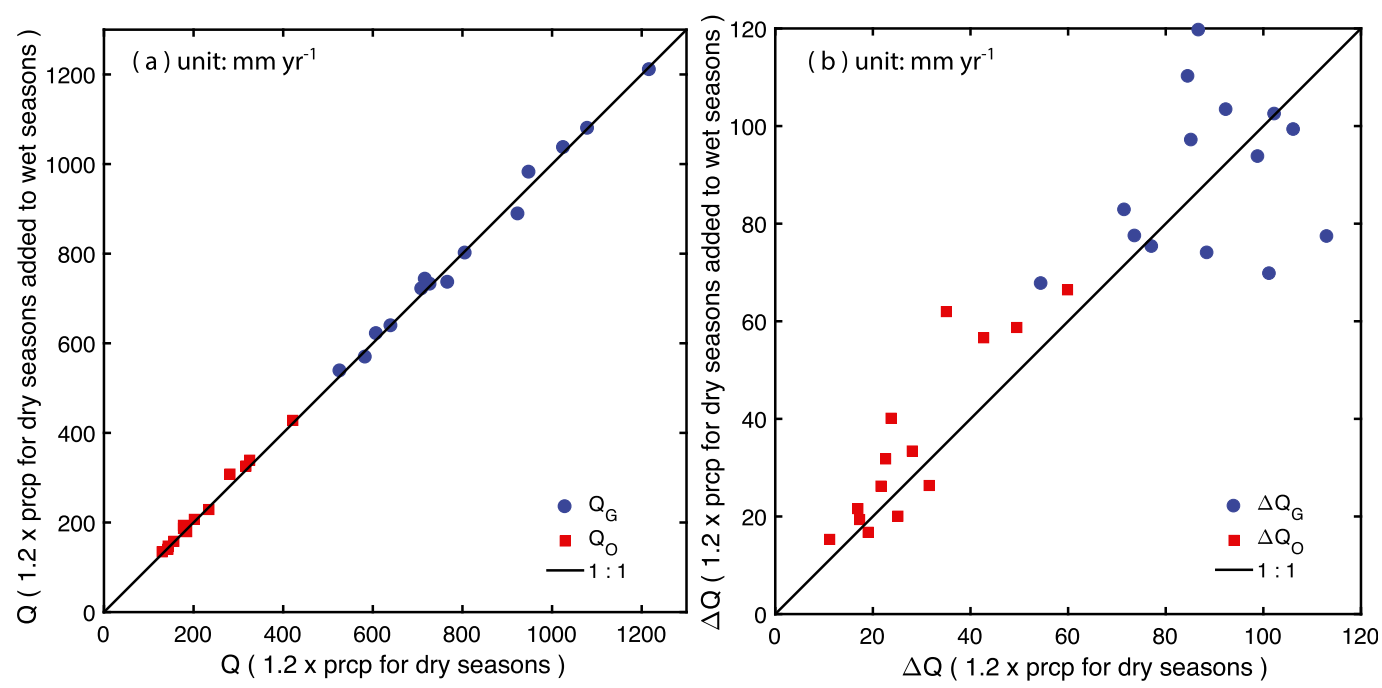

FIG. 8. (a) Scatterplot comparing simulated annual base flow when dry season rainfall (May-November, $x$ axis) is increased to $1.2 \times$ and when the same amount of rainfall is added to rainy days in the wet season (December-April, $y$ axis). Each point represents a year. (b) Changes in flow contribution, $\Delta Q=Q$ (perturbed) $-Q$, when the same amount of rainfall is added to different seasons. When rainfall is added to the wet season, there is notably more overland flow. However, there is no such systematic bias with base flow. Both plots show that $Q_{g}$ is controlled by AP but not the season in which rainfall is added.

and limited scatter around the 1-versus-1 line (Fig. 8a). Changes compared to the base case (Fig. 8b) indicate increased surface runoff for wet-season additions, reflecting increased saturation excess runoff, and no such bias for base flow. Such a pattern may be attributed to the slow response of the groundwater reservoir that suppresses the impacts of seasonal fluctuations. Since base flow is the dominant contribution of streamflow, the outcome is that annual streamflow is also strongly controlled by AP.

\section{e. Understanding controls of hydrologic budgets with temporal correlation analysis}

We performed temporal [region-averaged annual data (Fig. 9) and region-averaged monthly data (Fig. S3)] correlation analyses of the simulated results using the TRMM precipitation forcing. We verified that the correlation patterns are consistent regardless of the precipitation forcing used. The temporal analyses show the correlation of time series variation among hydrologic fluxes. Several conclusions result from these correlation analyses.

Temporal correlation of ET with precipitation is low $[r=0.15$ for monthly data (Fig. S3) and $r=0.53$ for annual average (Fig. 9), and the correlation is not significant]. This insensitivity to precipitation occurs 1 ) because ET is energy limited ( $r=0.55$ for monthly solar radiation versus ET, Fig. S3) and 2) because of differences in sign and magnitude of the three ET components: canopy evaporation is positively correlated with precipitation $(r=0.99$ monthly and $r=0.98$ annually), transpiration is negatively correlated with precipitation ( $r=-0.87$ monthly and $r=-0.85$ annually), and ground evaporation is correlated (but less strongly) with precipitation for monthly averages $(r=0.69$, Fig. S3) or not significantly correlated for annual average (Fig. 9). Even though the seasonal variation of temperature is small in tropical forests, ET is strongly correlated with it ( $r=0.7$ monthly), since the major component of ET, transpiration, is highly correlated with temperature ( $r=0.84$ monthly), while soil and canopy evaporation are not $(r=-0.33$ and $r=-0.65$, Fig. S3). Since averaging annual data smooth the seasonality, these correlations diminish in Fig. 9, but remain strong for temperature versus transpiration $(r=0.73)$. For monthly data, the correlation between transpiration and radiation is strong $(r=0.78)$, but since canopy evaporation is also highly negatively correlated with radiation $(r=-0.64)$, as with temperature $(r=-0.65)$, the correlation between ET and radiation $(r=0.55)$ is not as high as that with temperature $(r=0.7)$. The corresponding annual averaged correlations for these fluxes are all not significant (Fig. 9) since the annual average smooths out the seasonal variation of these fluxes. These simulation results indicate that the system is energy limited throughout much of the year. Therefore, seasonally, ET is more sensitive to changes in energy input than to precipitation, consistent with previous 

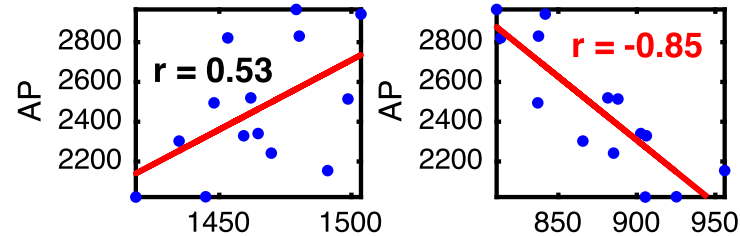

ET
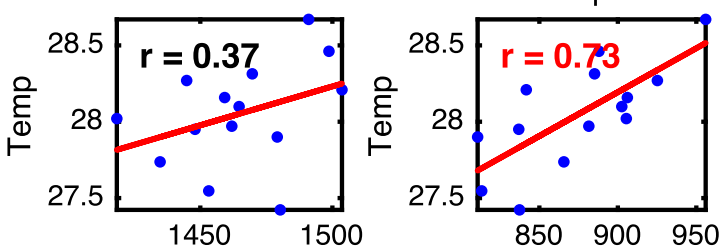

ET
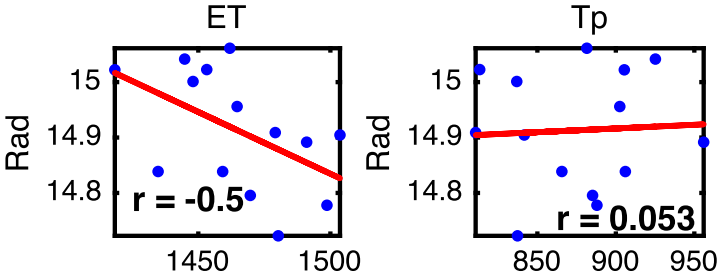

ET
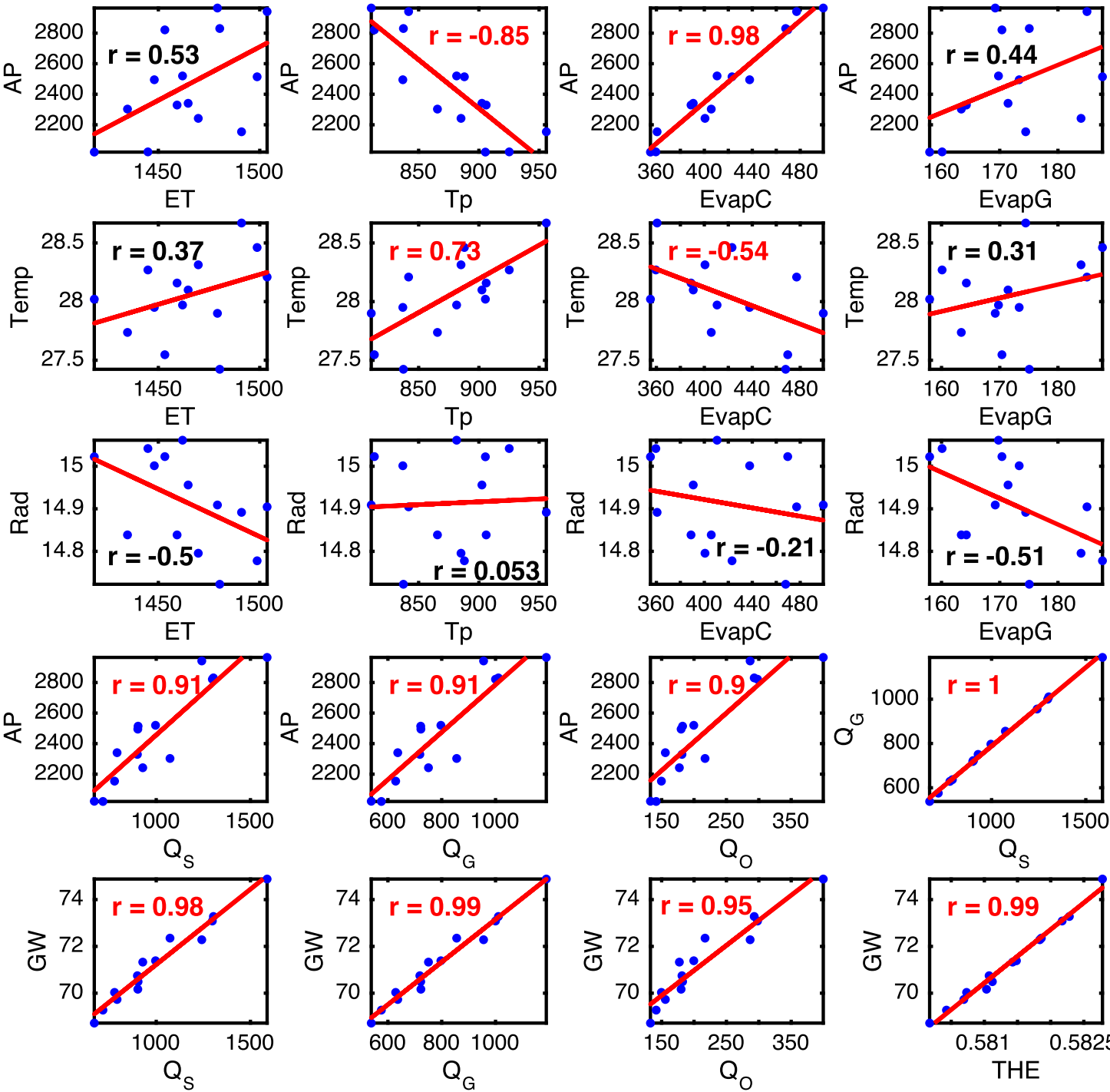

EvapC
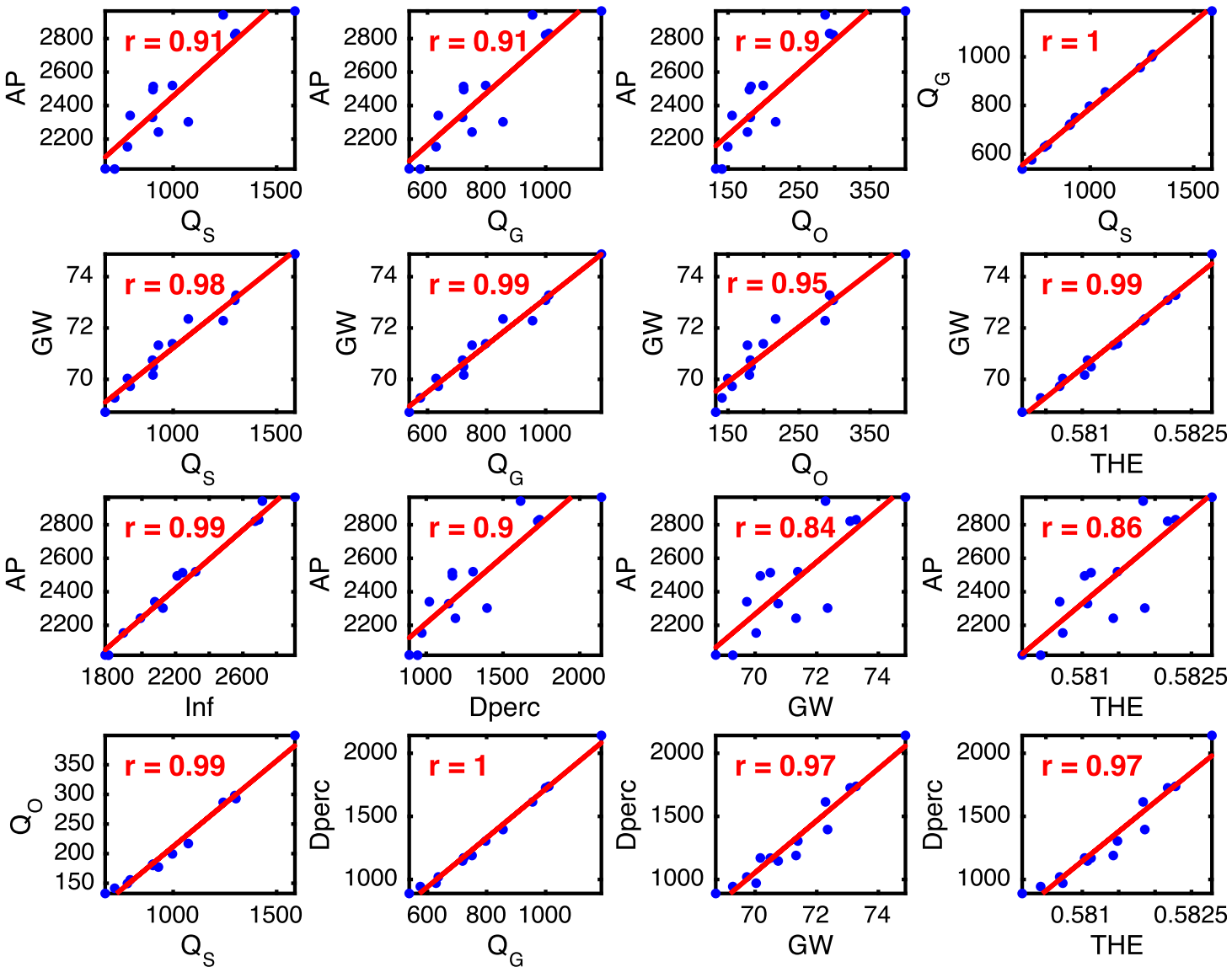

FIG. 9. Correlation plots for annual budgets of water fluxes. The correlation coefficients are shown in each subplot. The first three rows are the correlations of forcing data, precipitation, temperature, and radiation to ET and its components, transpiration, canopy evaporation, and ground evaporation. The fourth and fifth rows are the correlations of precipitation and groundwater head to streamflow and its components, contributed from groundwater and overland flow, but note the last column of the fourth row is the correlation between streamflow and its groundwater contribution. The sixth row is the 
studies across the Amazon (Negrón-Juárez et al. 2007; da Rocha et al. 2009) and the whole tropics (Fisher et al. 2009), as mentioned above.

We argue that the large infiltration rate, the stable energy inputs, the subsequent buffering by the groundwater reservoir, and the storage-dependent nature of surface runoff are the causes for the strong control of AP on these fluxes. Because of groundwater buffering and its dominant role, the interannual fluctuations in seasonal precipitation distribution do not significantly alter annual streamflow fluxes. Different precipitation datasets, with different distributions of magnitude, produce the same correlations. Groundwater and subsurface storage, which are controlled by AP, stabilize all fluxes. Since surface runoff is also storage-dependent, it is also controlled by AP. The outcome of this analysis is that, with only predictions about AP, one can reasonably well characterize streamflow changes for this upland basin.

That soil infiltration is more highly correlated with precipitation ( $r=0.99$ both annually and monthly) than surface runoff ( $r=0.33$ monthly and $r=0.9$ annually) is consistent with the high proportion of precipitation that becomes infiltration. Although it has been shown from other modeling studies that the spatial distribution of simulated total runoff is correlated to precipitation patterns (Getirana et al. 2014), we found that stream outflow and surface runoff are correlated more strongly to the subsurface fluxes and water budgets than to precipitation for both monthly and annual data. There are several predicted patterns suggesting rainfall rapidly becomes streamflow (through subsurface pathways): 1) surface runoff does not account for a significant portion of precipitation [section $3 b(2)$; Table 2], 2) ET is not strongly correlated with precipitation, 3 ) infiltration is highly correlated with precipitation, and 4) seasonal variation of soil moisture is small. Moreover, although the seasonal variation of soil moisture is relatively small, the values reported in Fig. 9 for soil moisture are monthly averaged and area averaged over the whole watershed, and the average over the entire soil profile of each 1-km grid; thus, a small variation represents large changes in soil water content. Soil moisture is also more strongly correlated to water table depth than to precipitation. Groundwater recharge and water table depth are weakly or not correlated to precipitation in the short term (Fig. S3); however, they are both highly correlated to precipitation in the long term (Fig. 9), indicating the slowly changing behavior for the subsurface hydrologic fluxes. These patterns again suggest the importance of groundwater to the water cycle of the $4 \mathrm{RR}$ watershed, which is consistent with previous studies from microcatchment scales (Lesack 1993; Tomasella et al. 2008) to the whole Amazon basin (Miguez-Macho and Fan 2012a,b).

The ratio between mean annual ET and total water loss (ET plus stream outflow $Q_{s}$ ) is negatively correlated with AP $(r=-0.88$, Fig. 10). The interannual variability of annual ET is small in this energy-limited basin, with muted variations in year-over-year energy inputs. As a result, ET does not depend on AP (result not shown). Therefore, we expect the interannual variability in precipitation will translate into variations in storage or runoff.

In contrast, some climate- and regional-scale land models (e.g., Kleidon and Heimann 2000; Werth and Avissar 2004; Baker et al. 2008; da Rocha et al. 2009) applied in the Amazon have predicted a water-limited ET seasonality that resembles the precipitation cycle. Consistent with our results, Shuttleworth (1988), based on observations and model syntheses, showed that ET in the dry and wet seasons are comparable in central Amazon evergreen forests. Recent studies based on eddy flux tower observations at site level (Hutyra et al. 2007), across the Amazon (Negrón-Juárez et al. 2007; da Rocha et al. 2009; Restrepo-Coupe et al. 2013; Christoffersen et al. 2014) and the whole tropics (Fisher et al. 2009) indicate seasonal ET is driven by radiation, rather than water availability. Getirana et al. (2014) also showed that ET does not depend on observed variations

\footnotetext{
correlation between precipitation and subsurface fluxes, including infiltration, deep percolation, groundwater head, and soil moisture. The first subplot on the last row is the correlation between streamflow and its overland flow contribution, whereas the rest of the subplots are the correlations of deep percolation to groundwater contribution to streamflow, groundwater head, and soil moisture. The Pearson linear correlation coefficients are shown in each subplot; black means correlation is not significant, as the $p$ value for testing the hypothesis of no correlation is larger than 0.05 , while red means significantly correlated. Abbreviations and units: AP $\left(\mathrm{mm} \mathrm{yr}^{-1}\right)$; Temp, temperature $\left({ }^{\circ} \mathrm{C}\right)$; Rad, radiation $\left(\mathrm{W} \mathrm{m}^{-2}\right)$; Dperc, groundwater recharge $\left(\mathrm{mm} \mathrm{yr}^{-1}\right) ; \mathrm{GW}$, groundwater head $(\mathrm{m})$; ET $\left(\mathrm{mm} \mathrm{yr}^{-1}\right)$; Tp, transpiration $\left(\mathrm{mm} \mathrm{yr}^{-1}\right)$; EvapC, canopy evaporation $\left(\mathrm{mm} \mathrm{yr}^{-1}\right)$; EvapG, ground evaporation $\left(\mathrm{mm} \mathrm{yr}^{-1}\right)$; Inf, infiltration $\left(\mathrm{mm} \mathrm{yr}^{-1}\right)$; THE, soil moisture (dimensionless); $Q_{G}$, groundwater outflow $\left(\mathrm{mm} \mathrm{yr}^{-1}\right) ; Q_{O}$, surface runoff $\left(\mathrm{mm} \mathrm{yr}^{-1}\right) ; Q_{S}$, watershed river outflow $\left(\mathrm{mm} \mathrm{yr}^{-1}\right)$.
} 


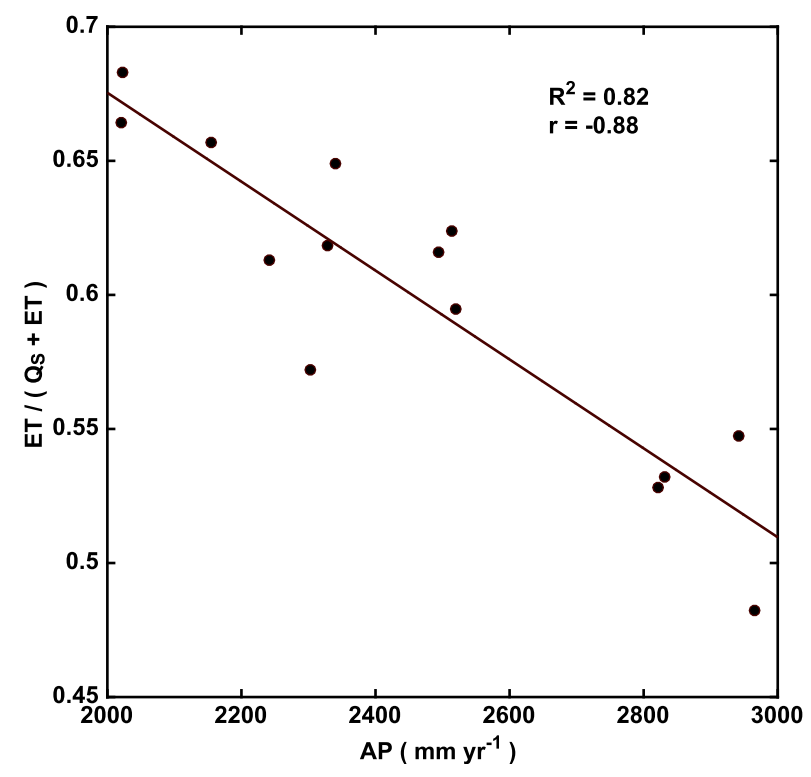

FIG. 10. The ratio of mean annual water losses through ET to the total water losses $\left(\mathrm{ET}+Q_{S}\right)$ and AP. Dots are the data, and the line is the linear fitting curve. The coefficient of determination for the linear fitting is $R^{2}=0.82$, and the correlation coefficient is $r=-0.88$.

in water availability over most of the Amazon basin. Our simulations support the "energy-limited ET" hypothesis for this part of the Amazon. As ET only uses part of the available water, with excess water infiltrating into the soil, we can anticipate some subsurface buffering capacity and resilience to moderate droughts even if vegetation maintains the same productivity.

The larger imprint of rainfall on ET with TRMM can be seen in Figs. 11a and 11b, showing the spatial heterogeneity of TRMM data and the impact of precipitation input on the ET simulation. Though the system is overall energy limited, the spatial pattern of predicted annual average ET is correlated to the spatial pattern of mean AP in both TRMM and CRUNCEP precipitation forced simulations ( $r=0.55$ for TRMM, Fig. S4), even though neither spatial variation is large because of the coarse resolution of the precipitation data. The predicted hydrologic budgets are not well correlated with soil type in our study (data not shown), because of the relatively homogeneous distribution of oxisols in the soil dataset we used, in which sand, clay, and organic matter content fractions have little variation, with only slight changes associated with surface elevation and slope. This finding supports the conclusion in Tang et al. (2015) that the effect of explicit parameterization of oxisol properties is small in simulated ET, partly due to the insufficiency of soil texture data.

\section{f. Limitations and future directions}

From the simulation results and correlation analyses discussed above, we conclude that improving watershed-scale tropical model predictions requires three advances: 1) improved and accurate meteorological forcing data at finer spatial resolution to regulate the spatial patterns of hydrologic fluxes, for example, ET and infiltration, and to better quantify the time series simulation of hydrologic fluxes, for example, stream discharge; 2 ) accurate soil texture data and soil hydraulic parameterizations for the tropics to improve the simulation of soil moisture and further improve the simulation of groundwater and vegetation dynamics; and 3) more watershed-scale observations of surface water and energy budgets, groundwater dynamics, and streamflows. In addition, more reliable elevation and initial water table depth data assure less simulation bias for, among others, surface runoff and groundwater recharge. In future work, an improved representation of deep rooting profiles and their hydraulic properties may be needed to improve the simulation of water movement below ground and impacts on plant processes.

\section{Conclusions}

Many hydrologic components in the 4RR watershed are sensitive to precipitation forcing, and there are significant differences between precipitation forcing datasets commonly used in tropical modeling analyses. However, evapotranspiration in this tropical forest is relatively insensitive to precipitation, which suggests ET is overall energy limited during the wet season. Groundwater buffers the effects of intense storms in the wet season and maintains soil moisture and stream discharge in the dry season. Most of the rainfall, even from most of the heavy storms, infiltrates and exits as groundwater flow. The buffering effect of groundwater means that with only predictions about mean annual precipitation, one can reasonably well characterize interannual streamflow changes for similar upland basins. Years with larger rainfall, that is, lower radiation, impose larger limitations on ET during the wet season while providing more water during the dry season. As ET is utilizing only a fraction of available water, this basin is energy limited. Combined with the large buffering effects of groundwater, some resilience for moderate droughts is expected. At the annual time scale, we found a strong negative correlation between $\mathrm{AP}$ and the ratio of mean annual ET to the total water loss of the watershed $\left(\mathrm{ET}+Q_{S}\right)$. In general, seasonal soil water availability is controlled by groundwater. Thus, even though dry season precipitation 


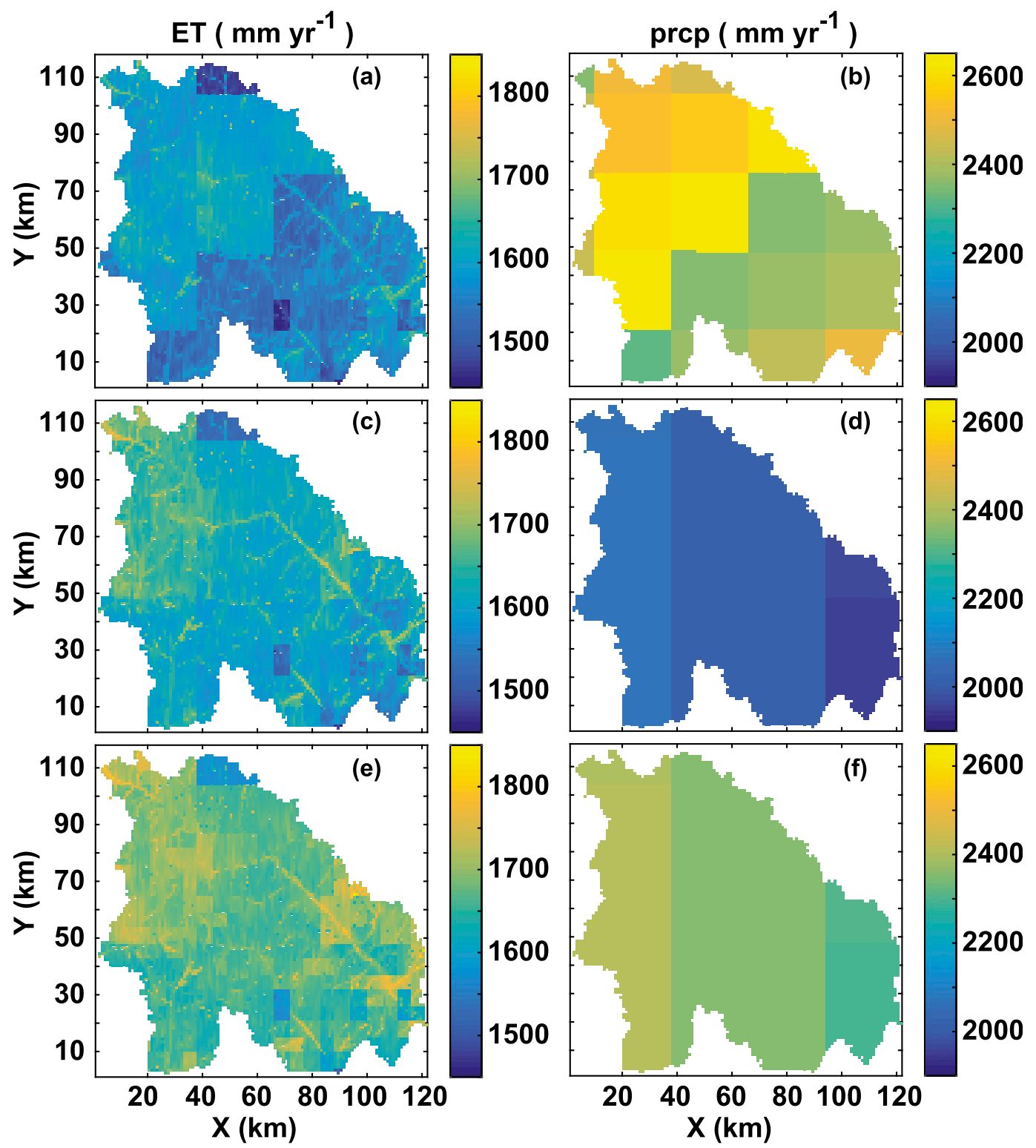

FIG. 11. Annual AP and ET maps showing the annual averaged ET maps simulated with (a) TRMM, (c) CRUNCEP rainfall, and (e) ZF2-K34 rainfall data; (b),(d),(f) the annual averaged data of precipitation maps for three rainfall input data.

is as much as $\sim 200 \mathrm{~mm}$ month $^{-1}$ lower than the wet season, the seasonal variation of ET is low, or slightly increases in the dry season due to increased solar radiation. Predicted ET is not correlated in time to precipitation primarily because of energy limitations, but is spatially correlated for the annual average of each grid cell. The fractional compositions of mean annual groundwater and overland flow contributing to streamflow are negatively and positively correlated to AP above $\sim 2500 \mathrm{~mm} \mathrm{yr}^{-1}$, respectively. We found that this value indicates an initiation threshold for saturation excess, below which the variation of the fractional composition (groundwater versus overland flow contributions) is small, and above which it grows rapidly. In contrast, base flow increases linearly with increasing AP. The groundwater supports the bulk of streamflow and dominates total water storage temporal variability.

Acknowledgments. This research was supported by the Director, Office of Science, Office of Biological and Environmental Research of the U.S. Department of 
Energy under Contract DE-0010620 as part of their Earth System Modeling and NGEE-Tropics Program. We thank the LBA and the LBA-Data-ModelIntercomparison project, which provided the datasets for comparison. We thank Jinyun Tang, Gautam Bisht, and Charles Koven for clarifying CLM input data. Datasets used as model inputs and for model testing are owned by several agencies or individual personnel, and details of these data sources are open to access online.

\section{REFERENCES}

Abril, G., S. Richard, and F. Guérin, 2006: In situ measurements of dissolved gases $\left(\mathrm{CO}_{2}\right.$ and $\left.\mathrm{CH}_{4}\right)$ in a wide range of concentrations in a tropical reservoir using an equilibrator. Sci. Total Environ., 354, 246-251, doi:10.1016/j.scitotenv.2004.12.051.

Baker, I. T., L. Prihodko, A. S. Denning, M. Goulden, S. Miller, and H. R. da Rocha, 2008: Seasonal drought stress in the Amazon: Reconciling models and observations. J. Geophys. Res., 113, G00B01, doi:10.1029/2007JB005423.

Beighley, R. E., K. G. Eggert, T. Dunne, Y. He, V. Gummadi, and K. L. Verdin, 2009: Simulating hydrologic and hydraulic processes through-out the Amazon River Basin. Hydrol. Processes, 23, 1221-1235, doi:10.1002/hyp.7252.

Bonan, G. B., S. Levis, L. Kergoat, and K. W. Oleson, 2002: Landscapes as patches of plant functional types: An integrating concept for climate and ecosystem models. Global Biogeochem. Cycles, 16, 1021, doi:10.1029/2000GB001360.

Buss, H. L., R. Mathur, A. F. White, and S. L. Brantley, 2010: Phosphorus and iron cycling in deep Saprolite, Luquillo Mountains, Puerto Rico. Chem. Geol., 269, 52-61, doi:10.1016/ j.chemgeo.2009.08.001.

Carabajal, C. C., and D. J. Harding, 2006: SRTM C-band and ICESat laser altimetry elevation comparisons as a function of tree cover and relief. Photogramm. Eng. Remote Sensing, 72, 287-298, doi:10.14358/PERS.72.3.287.

Chambers, J. Q., and D. A. Roberts, 2014: Ecology: Drought in the Congo Basin. Nature, 509, 36-37, doi:10.1038/nature13330.

Christoffersen, B. O., and Coauthors, 2014: Mechanisms of water supply and vegetation demand govern the seasonality and magnitude of evapotranspiration in Amazonia and Cerrado. Agric. For. Meteor., 191, 33-50, doi:10.1016/j.agrformet.2014.02.008.

Clark, M. P., and Coauthors, 2015: Improving the representation of hydrologic processes in Earth system models. Water Resour. Res., 51, 5929-5956, doi:10.1002/2015WR017096.

Coe, M. T., M. H. Costa, and E. A. Howard, 2008: Simulating the surface waters of the Amazon River basin: Impacts of new river geomorphic and flow parameterizations. Hydrol. Processes, 22, 2542-2553, doi:10.1002/hyp.6850.

Cuartas, L. A., 2008: Estudo observacional e de modelagem hidrologica de uma micro-bacia em floresta nao perturbada na Amazonia central. Ph.D. thesis, Instituto Nacional de Pesquisas Espaciais, $241 \mathrm{pp}$.

Czikowsky, M. J., and D. Fitzjarrald, 2009: Detecting rainfall interception in an Amazonian rainforest with eddy flux measurements. J. Hydrol., 377, 92-105, doi:10.1016/ j.jhydrol.2009.08.002.

Dai, Y. J., R. E. Dickinson, and Y. P. Wang, 2004: A two-bigleaf model for canopy temperature, photosynthesis, and stomatal conductance. J. Climate, 17, 2281-2299, doi:10.1175/ 1520-0442(2004)017<2281:ATMFCT>2.0.CO;2. da Rocha, H. R., H. C. Freitas, L. D. V. O. Pinto, M. C. Menton, M. Goulden, S. D. Miller, and A. M. S. Figueira, 2004: Seasonality of water and heat fluxes over a tropical forest in eastern Amazonia. Ecol. Appl., 14, 22-32, doi:10.1890/02-6001. , and Coauthors, 2009: Patterns of water and heat flux across a biome gradient from tropical forest to savanna in Brazil. J. Geophys. Res., 114, G00B12, doi:10.1029/2007JG000640.

Dingman, S. L., 2002: Physical Hydrology. 2nd ed. Prentice Hall, 600 pp.

Eaton, W. D., M. Roed, O. Chassot, and D. Barry, 2012: Differences in soil moisture, nutrients and the microbial community between forests on the upper Pacific and Caribbean slopes at Monteverde, Cordillera de Tilaran: Implications for responses to climate change. Trop. Ecol., 53, 235-240.

Fan, Y., H. Li, and G. Miguez-Macho, 2013: Global patterns of groundwater table depth. Science, 339, 940, doi:10.1126/ science. 1229881.

Fang, K., C. Shen, J. B. Fisher, and J. Niu, 2016: Improving Budyko curve-based estimates of long-term water partitioning using hydrologic signatures from GRACE. Water Resour. Res., 52, 5537-5554, doi:10.1002/2016WR018748.

Fisher, J. A., and Coauthors, 2009: The land-atmosphere water flux in the tropics. Global Change Biol., 15, 2694-2714, doi:10.1111/j.1365-2486.2008.01813.x.

Franken, W., and P. R. Leopoldo, 1984: The Amazon: Limnology and Landscape Ecology of a Mighty Tropical River and Its Basin. H. Sioli, Ed., W. Junk Publishers, 763 pp.

$\mathrm{Fu}, \mathrm{R}$., and W. Li, 2004: The influence of the land surface on the transition from dry to wet season in Amazonia. Theor. Appl. Climatol., 78, 1-3, doi:10.1007/s00704-004-0046-7.

Getirana, A. C. V., and Coauthors, 2014: Water balance in the Amazon Basin from a land surface model ensemble. J. Hydrometeor., 15, 2586-2614, doi:10.1175/JHM-D-14-0068.1.

Guan, K. Y., and Coauthors, 2015: Photosynthetic seasonality of global tropical forests constrained by hydroclimate. Nat. Geosci., 8, 284-289, doi:10.1038/ngeo2382.

Guber, A. K., Ya. A. Pachepsky, M. Th. van Genuchten, W. J. Rawls, J. Simunek, D. Jacques, T. J. Nicholson, and R. E. Cady, 2006: Field-scale water flow simulations using ensembles of pedotransfer functions for soil water retention. Vadose Zone J., 5, 234-247, doi:10.2136/vzj2005.0111.

,,,--- J. Šimůnek, D. Jacques, A. Nemes, T. J. Nicholson, and R. E. Cady, 2009: Multimodel simulation of water flow in a field soil using pedotransfer functions. Vadose Zone J., 8, 1-10, doi:10.2136/vzj2007.0144.

Hodnett, M. G., I. Vendrame, O. De, A. Marques Filho, M. D. Oyama, and J. Tomasella, 1997a: Soil water storage and groundwater behavior in a catenary sequence beneath forest in central Amazonia: I. Comparisons between plateau, slope and valley floor. Hydrol. Earth Syst. Sci., 1, 265-277, doi:10.5194/hess-1-265-1997.

$\leftarrow,-,-,-, \ldots$, and $\_, 1997 b$ : Soil water storage and groundwater behavior in a catenary sequence beneath forest in central Amazonia: II. Floodplain water table behavior and implications for streamflow generation. Hydrol. Earth Syst. Sci., 1, 279-290, doi:10.5194/hess-1-279-1997.

Hutyra, L. R., and Coauthors, 2007: Seasonal controls on the exchange of carbon and water in an Amazonian rain forest. J. Geophys. Res., 112, G03008, doi:10.1029/2006JG000365.

Ivanov, V. Y., E. R. Vivoni, R. L. Bras, and D. Entekhabi, 2004: Catchment hydrologic response with a fully distributed triangulated irregular network model. Water Resour. Res., 40, W11102, doi:10.1029/2004WR003218. 
Ji, X., C. Shen, and W. J. Riley, 2015: Temporal evolution of soil moisture statistical fractal and controls by soil texture and regional groundwater flow. Adv. Water Resour., 86, 155-169, doi:10.1016/j.advwatres.2015.09.027.

Jia, Y., H. Wang, Z. Zhou, Y. Qiu, X. Luo, J. Wang, D. Yan, and D. Qin, 2006: Development of the WEP-L distributed hydrological model and dynamic assessment of water resources in the Yellow River basin. J. Hydrol., 331, 606-629, doi:10.1016/j.jhydrol.2006.06.006.

Kleidon, A., and M. Heimann, 2000: Assessing the role of deep rooted vegetation in the climate system with model simulations: Mechanism, comparison to observations and implications for Amazonian deforestation. Climate Dyn., 16, 183-199, doi:10.1007/s003820050012.

Lawrence, D. M., and Coauthors, 2011: Parameterization improvements and functional and structural advances in version 4 of the community land model. J. Adv. Model. Earth Syst., 3, M03001, doi:10.1029/2011MS00045.

Lee, J. E., R. S. Oliveira, T. E. Dawson, and I. Fung, 2005: Root functioning modifies seasonal climate. Proc. Natl. Acad. Sci. USA, 102, 17 576-17 581, doi:10.1073/pnas.0508785102.

Leopoldo, P. R., W. K. Franken, and N. A. Villa Nova, 1995: Real evapotranspiration and transpiration through a tropical rain forest in central Amazonia as estimated by the water balance method. For. Ecol. Manage., 73, 185-195, doi:10.1016/ 0378-1127(94)03487-H.

Lesack, L. F. W., 1993: Water balance and hydrologic characteristics of a rain forest catchment in the central Amazon Basin. Water Resour. Res., 29, 759-773, doi:10.1029/92WR02371.

— catchment in the central Amazon basin: Implications for elemental budgets in tropical rainforests. Biogeochemistry, 32, 115-142, doi:10.1007/BF00000355.

Marengo, J. A., 2004: Interdecadal variability and trends of rainfall across the Amazon basin. Theor. Appl. Climatol., 78, 79-96, doi:10.1007/s00704-004-0045-8.

- 2005: Characteristics and spatio-temporal variability of the Amazon River basin water budget. Climate Dyn., 24, 11-22, doi:10.1007/s00382-004-0461-6.

Markewitz, D., S. Devine, E. A. Davidson, P. Brando, and D. C. Nepstad, 2010: Soil moisture depletion under simulated drought in the Amazon: Impacts on deep root uptake. New Phytol., 187, 592-607, doi:10.1111/j.1469-8137.2010.03391.x.

Maxwell, R. M., and N. L. Miller, 2005: Development of a coupled land surface and groundwater model. J. Hydrometeor., 6, 233-247, doi:10.1175/JHM422.1.

Melack, J. M., 2016: Aquatic ecosystems. Interactions between Biosphere, Atmosphere and Human Land Use in the Amazon Basin, L. Nagy, B. Forsberg, and P. Artaxo, Eds., Ecological Studies, Vol. 227, Springer, 117-145.

Miguez-Macho, G., and Y. Fan, 2012a: The role of groundwater in the Amazon water cycle: 1 . Influence on seasonal streamflow, flooding and wetlands. J. Geophys. Res., 117, D15113, doi:10.1029/2012JD017539.

—_, and —_, 2012b: The role of groundwater in the Amazon water cycle: 2 . Influence on seasonal soil moisture and evapotranspiration. J. Geophys. Res., 117, D15114, doi:10.1029/2012JD017540.

Morton, D. C., and Coauthors, 2014: Amazon forests maintain consistent canopy structure and greenness during the dry season. Nature, 506, 221-224, doi:10.1038/nature13006.

$\mathrm{Mu}$, Q., F. A. Heinsch, M. Zhao, and S. W. Running, 2007: Development of a global evapotranspiration algorithm based on MODIS and global meteorology data. Remote Sens. Environ., 111, 519-536, doi:10.1016/j.rse.2007.04.015.

—, M. Zhao, and S. W. Running, 2011: Improvements to a MODIS global terrestrial evapotranspiration algorithm. Remote Sens. Environ., 115, 1781-1800, doi:10.1016/j.rse.2011.02.019.

Negrón-Juárez, R. I., M. G. Hodnett, R. Fu, M. Goulden, and C. von Randow, 2007: Control of dry season evapotranspiration over the Amazonian forests as inferred from observations at a southern Amazon forest site. J. Climate, 20, 2827-2839, doi:10.1175/JCLI4184.1.

Niu, G.-Y., C. Paniconi, P. A. Troch, R. L. Scott, M. Durcik, X. Zeng, T. Huxman, and D. C. Goodrich, 2014: An integrated modeling framework of catchment-scale ecohydrological processes: 1 . Model description and tests over an energy-limited watershed. Ecohydrology, 7, 427-439, doi:10.1002/eco.1362.

Niu, J., and M. S. Phanikumar, 2015: Modeling watershed-scale solute transport using an integrated, process-based hydrologic model with applications to bacterial fate and transport. J. Hydrol., 529, 35-48, doi:10.1016/j.jhydrol.2015.07.013.

_ C. Shen, S.-G. Li, and M. S. Phanikumar, 2014: Quantifying storage changes in regional Great Lakes watersheds using a coupled subsurface-land surface process model and GRACE, MODIS products. Water Resour. Res., 50, 7359-7377, doi:10.1002/2014WR015589.

Nobre, A. D., L. A. Cuartas, M. Hodnett, C. D. Renn, G. Rodrigues, A. Silveira, M. Waterloo, and S. Saleska, 2011: Height above the nearest drainage-A hydrologically relevant new terrain model. J. Hydrol., 404, 13-29, doi:10.1016/ j.jhydrol.2011.03.051.

Oleson, K. W., and Coauthors, 2010: Technical description of version 4.0 of the Community Land Model (CLM). NCAR Tech. Note NCAR/TN-478+STR, 257 pp., doi:10.5065/D6FB50WZ.

— , and Coauthors, 2013: Technical description of version 4.5 of the Community Land Model (CLM). NCAR Tech. Note NCAR/TN-503+STR, 420 pp., doi:10.5065/D6RR1W7M.

Paiva, R. C. D., D. C. Buarque, W. Collischonn, M.-P. Bonnet, F. Frappart, S. Calmant, and C. A. B. Mendes, 2013: Large-scale hydrologic and hydrodynamic modeling of the Amazon River basin. Water Resour. Res., 49, 1226-1243, doi:10.1002/wrcr.20067.

Pau, G. S. H., C. Shen, W. J. Riley, and Y. Liu, 2016: Accurate and efficient prediction of fine-resolution hydrologic and carbon dynamic simulations from coarse-resolution models. Water Resour. Res., 52, 791-812, doi:10.1002/2015WR017782.

Pelletier, J. D., and Coauthors, 2016: A gridded global data set of soil, intact regolith, and sedimentary deposit thicknesses for regional and global land surface modeling. J. Adv. Model. Earth Syst., 8, 41-65, doi:10.1002/2015MS000526.

Piao, S. L., and Coauthors, 2012: The carbon budget of terrestrial ecosystems in East Asia over the last two decades. Biogeosciences, 9, 3571-3586, doi:10.5194/bg-9-3571-2012.

Pokhrel, Y. N., Y. Fan, G. Miguez-Macho, P.-J. F. Yeh, and S. Han, 2013: The role of groundwater in the Amazon water cycle: 3. Influence on terrestrial water storage computations and comparison with GRACE. J. Geophys. Res. Atmos., 118, 3233-3244, doi:10.1002/jgrd.50335.

Price, K., R. M. Storn, and J. A. Lampinen, 2005: Differential Evolution: A Practical Approach to Global Optimization. Springer, 539 pp., doi:10.1007/3-540-31306-0.

Proctor, J., 2004: Rainforest mineral nutrition: The 'black box' and a glimpse inside it. Forests, Water and People in the Humid Tropics, M. Bonell and L. A. Bruijnzeel. Eds., Cambridge University Press, 422-446. 
Restrepo-Coupe, N., and Coauthors, 2013: What drives the seasonality of photosynthesis across the Amazon basin? A crosssite analysis of eddy flux tower measurements from the Brasil flux network. Agric. For. Meteor., 182-183, 128-144, doi:10.1016/j.agrformet.2013.04.031.

Richey, J. E., J. M. Melack, A. K. Aufdenkampe, V. M. Ballester, and L. L. Hess, 2002: Outgassing from Amazonian rivers and wetlands as a large tropical source of atmospheric $\mathrm{CO}_{2}$. Nature, 416, 617-620, doi:10.1038/416617a.

Rigon, R., G. Bertoldi, and T. M. Over, 2006: GEOtop: A distributed hydrological model with coupled water and energy budgets. J. Hydrometeor., 7, 371-388, doi:10.1175/JHM497.1.

Riley, W. J., and C. Shen, 2014: Characterizing coarse-resolution watershed soil moisture heterogeneity using fine-scale simulations. Hydrol. Earth Syst. Sci., 18, 2463-2483, doi:10.5194/hess-18-2463-2014.

Shanley, J. B., W. H. McDowell, and R. F. Stallard, 2011: Longterm patterns and short-term dynamics of stream solutes and suspended sediment in a rapidly weathering tropical watershed. Water Resour. Res., 47, W07515, doi:10.1029/ 2010WR009788.

Shen, C., and M. S. Phanikumar, 2010: A process-based, distributed hydrologic model based on a large-scale method for surface subsurface coupling. Adv. Water Resour., 33, 1524-1541, doi:10.1016/j.advwatres.2010.09.002.

_ - J. Niu, and M. S. Phanikumar, 2013: Evaluating controls on coupled hydrologic and vegetation dynamics in a humid continental climate watershed using a subsurface-land surface processes model. Water Resour. Res., 49, 2552-2572, doi:10.1002/wrcr.20189.

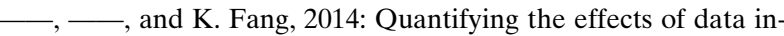
tegration algorithms on the outcomes of a subsurface-land surface processes model. Environ. Modell. Software, 59, 146-161, doi:10.1016/j.envsoft.2014.05.006.

- W. J. Riley, K. R. Smithgall, J. M. Melack, and K. Fang, 2016: The fan of influence of streams and channel feed- backs to simulated land surface water and carbon dynamics. Water Resour. Res., 52, 880-902, doi:10.1002/ 2015 WR018086.

Shuttleworth, W. J., 1988: Evaporation from Amazonian rainforest. Proc. Roy. Soc. London, B233, 321-346, doi:10.1098/ rspb.1988.0024.

Simard, M., N. Pinto, J. B. Fisher, and A. Baccini, 2011: Mapping forest canopy height globally with spaceborne lidar. J. Geophys. Res., 116, G04021, doi:10.1029/2011JG001708.

Stocker, T. F., and Coauthors, 2013: Technical summary. Climate Change 2013: The Physical Science Basis, T. F. Stocker et al., Eds., Cambridge University Press, 33-115, http://www.ipcc.ch/ pdf/assessment-report/ar5/wg1/WG1AR5_TS_FINAL.pdf.

Tang, J., W. J. Riley, and J. Niu, 2015: Incorporating root hydraulic redistribution in CLM4.5: Effects on predicted site and global evapotranspiration, soil moisture, and water storage. J. Adv. Model. Earth Syst., 7, 1828-1848, doi:10.1002/2015MS000484.

Tian, Y., and Coauthors, 2015: Exploring scale-dependent ecohydrological responses in a large endorheic river basin through integrated surface water-groundwater modeling. Water Resour. Res., 51, 4065-4085, doi:10.1002/2015WR016881.

Tomasella, J., and M. G. Hodnett, 1998: Estimating soil water retention characteristics from limited data in Brazilian Amazonia. Soil Sci., 163, 190-202, doi:10.1097/00010694199803000-00003.

$\longrightarrow,-$, L. A. Cuartas, A. D. Nobre, M. J. Waterloo, and S. M. Oliveira, 2008: The water balance of an Amazonian microcatchment: The effect of interannual variability of rainfall on hydrological behavior. Hydrol. Processes, 22, 2133-2147, doi:10.1002/hyp.6813.

Wang, D., G. Wang, and E. N. Anagnostou, 2007: Evaluation of canopy interception schemes in land surface models. J. Hydrol., 347, 308-318, doi:10.1016/j.jhydrol.2007.09.041.

Werth, D., and R. Avissar, 2004: The regional evapotranspiration of the Amazon. J. Hydrometeor., 5, 100-109, doi:10.1175/ 1525-7541(2004)005<0100:TREOTA > 2.0.CO;2. 